\title{
14
}

\section{A view from the west: A structural approach to analysing Lapita design in the Eastern Lapita Province}

\author{
Kathleen LeBlanc, Stuart Bedford and Christophe Sand
}

\begin{abstract}
Lapita ceramic design analysis has for decades been dominated by the element-motif approach. Here we outline a structural approach for the analysis of Lapita decoration that looks at design density, layout and organisation. It is used and compared to results from element-motif analysis to assess variation within the Eastern Lapita Province. Ceramic samples from both the Southern and Western Lapita Provinces are added to the analysis to assess how cohesive the Eastern Lapita Province is in terms of ceramic design. The results suggest that the concept of 'Provinces' requires some reassessment and redefinition.
\end{abstract}

\section{Introduction}

Lapita ceramic design analysis has been largely dominated by the element-motif approach. This involves dividing decorative designs into elements, 'a decorative unit executed by one single act' (Chiu 2003:226) and motifs, 'the succession of one design element, used as a fixed set to be combined with other design elements' (Chiu and Sand 2005:138). Such analysis is often used to understand patterns of migration and interaction, with design motifs widely used to identify regions of stylistic homogeneity, referred to as 'Provinces' (Green 1979; Kirch 1997). However, lack of consensus among archaeologists in both the Lapita region and in crosscultural perspective as to what these attributes represent has brought about confusion and nonstandardised methods surrounding design classification and comparison (Arnold 1983; Jernigan 1986; Plog 1980:40-55).

Structural design analysis provides an alternative approach (Canouts 1991; Hardin 1984; Hegmon 1994, 1995; Hegmon and Kulow 2005). It involves assessing the layout and organisation of design, including measurement of tool shape and spacing, semiotic analysis of design application and hierarchical descriptions of design zone patterning, among other attributes. More objective comparisons within and between ceramic assemblages can be undertaken because several of these attributes can be directly measured. Such approaches were suggested as early as the late 1950s in general and in the 1960s and '70s in Lapita archaeology specifically (Carlson 1961; Friedrich 1970; Mead et al. 1975; Sharp 1988; Shaw 1975; Shepard 1956; Washburn 1977, 1983). However, the lack of complete vessels and/or large sherds delayed the uptake of such an 
approach (Canouts 1991; Plog 1980). Studies of the structural application of ceramic design outside of the Lapita realm, particularly within an ethnoarchaeological context, have suggested that elements-motifs are passed on within and between generations through different mechanisms of transmission than those through which structural attributes are learned. Such results question the utility of relying solely on one form of design to answer larger questions of social interaction.

A combined element-motif and structural approach has been advocated for use in Lapita archaeology, such as that discussed by Chiu and Sand (2005) and Carson and colleagues (Carson et al. 2013). Despite the call, examples of use are few are far between (although see Clark et al. this volume). Here, a structural approach related to design density, layout and organisation of design, developed by LeBlanc (2016a), is used and compared to results from element-motif analysis to understand variation within the Eastern Lapita Province, a region where interaction is currently debated (Burley and LeBlanc 2015; Clark and Anderson 2009; Clark and Murray 2006; Cochrane and Lipo 2010; LeBlanc 2016a). To determine if ceramic design variability, or lack thereof, in the Eastern Lapita Province is characteristic of the region or is shared more broadly throughout the Lapita range, ceramic samples from both the Southern and Western Lapita Provinces are added to the analysis.

Observation of Lapita ceramic design density and the analysis of design elements-motifs in particular, has led to the hypothesis that more densely applied and intricate dentate designs appear early in the western sphere and subsequently decrease as Lapita potters move eastward (Burley et al. 2002; Green 1979; Kirch 1997; Sheppard 2011). The least densely applied and simplest motif repertoire is attributed to the later arrival of Lapita peoples in the Eastern Lapita Province (Burley et al. 2002, 2015). If this holds true, then measurable attributes of dentate density and size-shape should differ between the three provinces. If Eastern Lapita represents a distinct regional boundary, then variation within this region should be less than variation between regions. This hypothesis will be tested using both the element-motif and structural approach. The structural approach will be able to quantify patterning in design density and layout, characteristics that have not yet been used to test variation within and between Lapita provinces (aside from LeBlanc 2016a, 2016b). Utilising microscopy techniques, this approach will be used to test the following null hypothesis:

The distribution of elements-motifs and structural attributes of Lapita design do not vary between the Eastern, Western and Southern Lapita Provinces.

\section{Context for the development of a structural approach}

Early systems of Lapita design analysis, developed by Mead (1975) and applied by several scholars (Donovan 1973; Kirch 1988; Sharp 1988), followed a semiotic approach focused on process rules of motif application, with the aim of developing a 'grammar' of Lapita design. Sharp (1988) built upon the Mead (1975) system by analysing the rules behind which design elements were combined to form more complex motifs. Although an important step in applying structural analysis to Lapita design, this approach was short-lived, as it required large sherds with sufficient decoration.

The semiotic system was replaced by the motif method. This approach first necessitates that all possible motifs in a ceramic assemblage be defined, according to previously compiled lists for the Lapita region in question (such as Anson 1983; Mead 1975; Poulsen 1987). Comparison of motif presence/absence and/or frequency between ceramic assemblages then proceeds. This approach has dominated Lapita ceramic design analysis since the 1980s. 
One issue with relying on the motif approach to the exclusion of other methods is that we do not know what motifs meant to Lapita peoples, although it has been argued that they may have signalled house-group membership and position within the social hierarchy (Chiu 2007; Kirch 1997). While similarity in motifs could signal interaction, it is also likely that it reflects origins of common ancestry. Given similarity in Lapita motifs throughout the entire range (Summerhayes 2000), it is conceivable that the sharing of specific motifs indicate that initial settlers originated from a similar region. Design elements and motifs may persist through time and space but the ways in which they are applied to a vessel surface may change after settlement depending on learning patterns.

Regardless of which method is more appropriate, the motif approach in Lapita archaeology masks the complexity with which motifs are applied to a vessel surface. Several different archaeological assemblages within the Lapita range share similar motifs, but the density with which the motifs are applied varies widely. This difference in motif application has been noted (Chiu and Sand 2005; Clark and Anderson 2009; Cochrane and Lipo 2010), but the complexity of design application has not yet been quantified (although see LeBlanc 2016a, 2016b).

Reliance on the element-motif approach has led to debate surrounding similarity in ceramic style for West Fiji, Lau and Tonga in the Eastern Lapita Province (Burley 2013; Burley and LeBlanc 2015; Clark and Murray 2006; Cochrane and Lipo 2010). Archaeological ceramic evidence of the Lapita sequence in Lau appears to mirror that of Tonga (Best 1984; Burley 2013). The analysis of ceramic motifs, however, provides contradictory results to questions of migration and interaction in the Eastern Lapita Province. Best's (1984) use of the Robinson and Jaccard coefficients to analyse the frequency and presence/absence of design motifs indicates greater similarity between Lau and Tonga, than with West Fiji. The most recent analyses of the frequency of ceramic motifs, however, appears to contradict this patterning and instead suggests that Lau was settled from and interacted with both West Fiji and Tonga during the Lapita period through predominately peerto-peer transmission (Clark and Murray 2006; Cochrane and Lipo 2010). Differences in results appear to centre on variation in sample size and statistical methodology. Here we use a structural approach, analysing both elements-motifs and structural characters of design application to test the degree of similarity in ceramic design between samples from West Fiji, Lau, Tonga and the Western and Southern Lapita Provinces. It is clear, even to an untrained eye, that the density of design differs between these regions.

Recent advances in microscopy allow for more accurate measurement of design on sherds once considered too small for structural analysis. Illuminated light stereomicroscopy and laser scanning confocal microscopy are utilised here to test whether structural ceramic design attributes differ between Lapita provinces and whether such results mimic those from element-motif analysis.

If differences within the Eastern Lapita Province are less than differences between groups to the south and west, then this will suggest support for the Province model. If samples from within the Eastern Lapita Province align more with samples from the Southern and Western Provinces, then the Province categorisation will be questioned. If this occurs, the next step is to determine if attribute type plays a role; more specifically, if structural attributes provide a pattern that is inconsistent with element-motif attributes. 


\section{Methods}

In total, 17 attributes were chosen for analysis. These were divided into continuous and nominal categories. Continuous variables consist of dentate width, length, density, spacing, depth, area, surface area, volume and the number of elements-motifs-processes per sherd. Nominal variables consist of zone direction, frequency of elements-motifs-processes per sherd, infilling of motifs, symmetry, lime filling and slip (Table 14.1).

Table 14.1. Attributes used to analyse Lapita ceramic design.

\begin{tabular}{|l|l|}
\hline Attribute & Description \\
\hline Zones & $\begin{array}{l}\text { The direction of application (i.e. does the zone divide the design space into horizontal and/or } \\
\text { vertical segments?) (Figure 14.6). }\end{array}$ \\
\hline Elements & $\begin{array}{l}\text { Code based on Chiu and Sand (2005), but with additional descriptions and categories added } \\
\text { (see Table 14.2). }\end{array}$ \\
\hline Motifs & Code based on Mead (1975) and Poulsen (1987) categories. \\
\hline Infilling of motifs & Presence/absence of elements placed within known motif categories. \\
\hline Process & $\begin{array}{l}\text { Relationships between motifs as outlined in Sharp (1988). Refers to the process applied } \\
\text { to elements to create a motif (Figure 14.5). }\end{array}$ \\
\hline Symmetry & $\begin{array}{l}\text { Description of the motion of element-motif repetition. Notation system used is that of Washburn } \\
\text { and Crowe (1988). }\end{array}$ \\
\hline Lime filling & Indication of the presence/absence of lime used to fill dentate impressions. \\
\hline Slip & Indication of the presence/absence of slip applied to the vessel surface. \\
\hline Dentate length & Length of a single dentate tooth impression (Figures 14.1, 14.2). \\
\hline Dentate width & Width of a single dentate tooth impression (Figures 14.1, 14.2). \\
\hline Dentate depth & Depth of a single dentate tooth impression (Figure 14.3). \\
\hline Dentate area & Area of a single dentate tooth impression (Figure 14.4). \\
\hline Dentate surface area & Surface area of a single dentate tooth impression (Figure 14.4). \\
\hline Dentate volume & Volume of a single dentate tooth impression (Figure 14.4). \\
\hline Dentate spacing 1 & $\begin{array}{l}\text { Measurement of space between a single dentate tooth impression and those to either side } \\
\text { (Figure 14.1). }\end{array}$ \\
\hline Dentate spacing 2 & $\begin{array}{l}\text { Measurement of space between a single dentate tooth impression and the closest dentate- } \\
\text { stamped line (Figure 14.1). }\end{array}$ \\
\hline Dentate density & Number of dentate-stamped lines within a 1 cm2 area (Figure 14.1). \\
\hline
\end{tabular}

Source: Table prepared by Kathleen LeBlanc. See also references in table.

\section{Continuous attributes}

Structural continuous attributes that could be measured were sought in addition to nominal attributes as a means of quantifying design complexity and to enable small sherds to be analysed. Anyone performing a visual inspection of pottery design from the Eastern Lapita region, even by those unfamiliar with Lapita ceramics, can easily distinguish those originating in West Fiji and those from Tonga based on the density of application of design elements and motifs, even when contemporaneous sherds are compared (Burley et al. 2002). When East Fiji is added into the mix, design execution appears to mirror that of Tongan sherds, less dense than designs applied on West Fijian sherds and sherds found in regions outside of the Eastern Lapita Province. For this reason, attributes that could account for this variation in design execution were sought, resulting in the use of dentate density and recording of the spacing between individual dentate teeth and dentate-stamped tool impressions.

Two microscopes were utilised for the measurement of continuous variables. The first was a Leica MZ6 modular stereomicroscope (hereafter referred to as the Leica). It uses incident light illumination and has a 6.3:1 zoom. This microscope was used to measure dentate width, 
length, spacing 1 and 2, along with density (see Figure 14.1). Samples were magnified using 6.3-8.0x lenses, with a total magnification of 6.3-8.0x and a field diameter of 33.3$26.3 \mathrm{~mm}$. Resulting images were imported into Adobe Photoshop ${ }^{\otimes}$ to record measurements. A detailed description of how attributes were measured can be found in LeBlanc (2016a). Six measures were recorded for each attribute, aside from dentate density, to provide a representative sample of dentate size from different areas of a single sherd. Given that these data points do not meet the assumption of independence, the mean of the six measures was tabulated and used for statistical testing.

A second microscope was used to gain more insight into the size and shape of dentate impressions. This was an Olympus LEXT 4000 (hereafter referred to as the LEXT), a laser scanning confocal microscope designed for nanometre-level 3D imaging. This microscope has a dual confocal system and a $405 \mathrm{~nm}$ laser, which enables a magnification range of $108 \mathrm{x}-17280 \mathrm{x}$. The LEXT is used here to measure dentate length, width (Figure 14.2), depth (Figure 14.3), volume, surface area, and area (Figure 14.4) in a non-destructive manner. Three measures for each attribute were recorded per sherd, followed by taking the mean.

It is important to note that these attributes refer to dentate size and spacing between individual dentate teeth, while measures of design structure are indicative of the tools used to produce design. The dentate tools have not to date been identified in Lapita sites (Ambrose 2007), but it is possible that they may have differed in form and could have been made by different individuals than those who decorated vessels. In addition, potters who applied these tools are likely to have differed in their level of skill. Despite this, the goal of this structural analysis is not to identify individual potters, but to identify regions of stylistic homogeneity. For this reason, attributes that relate to tool size and spacing are worthy of consideration, as these aspects of Lapita ceramic design may have been subject to variation during the mechanisms of cultural transmission.
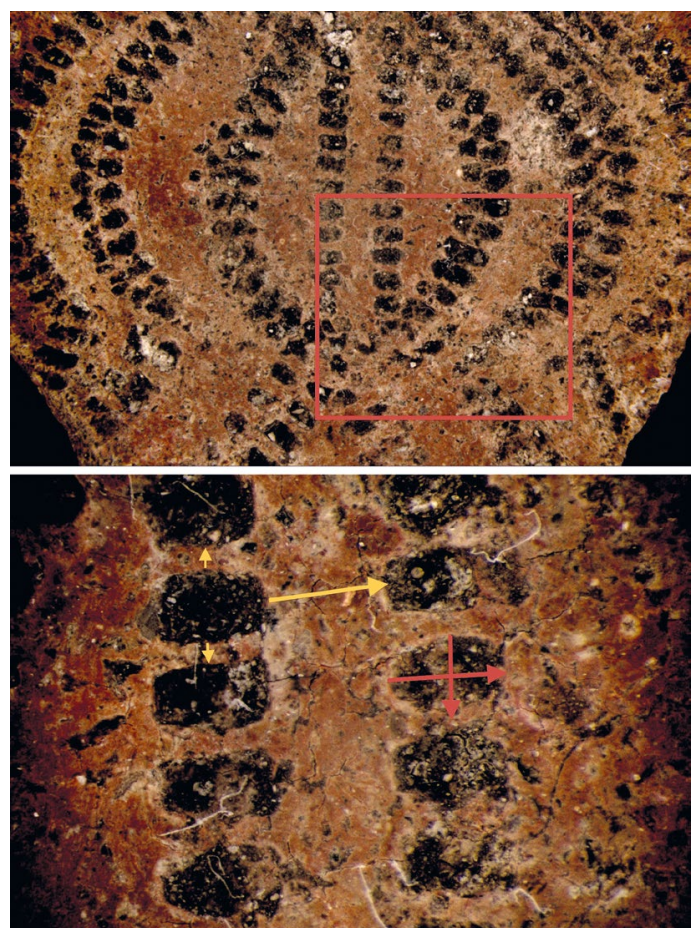

Figure 14.1. Sherd K1-5 from Kavewa, Fiji, magnified with the Leica MZ6 stereomicroscope.

Image on top magnified 6.3x and image on bottom magnified 25x. Image on the top shows a $1 \mathrm{~cm}$ square used to measure dentate density. Image on the bottom indicates spacing measurements (small orange arrows represent spacing 1, large orange arrow represents spacing 2) and dentate length-width measurements (red arrows).

Source: Kathleen LeBlanc.

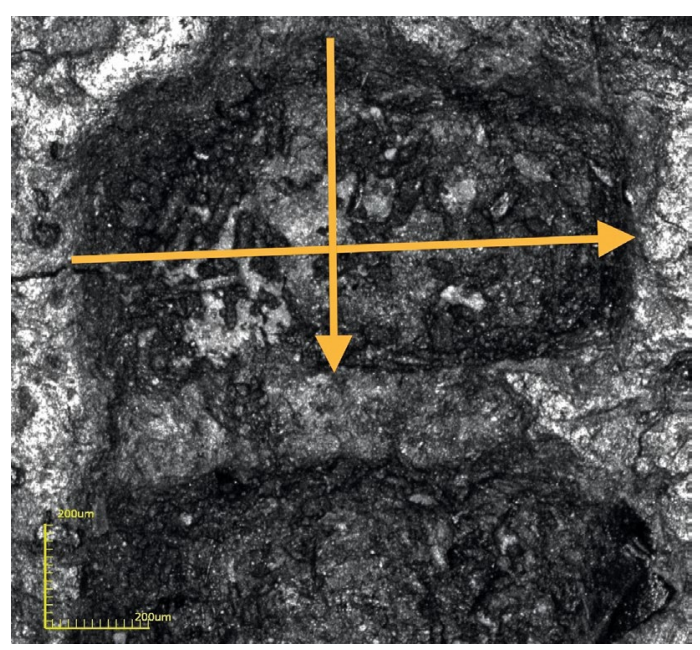

Figure 14.2. Image from Olympus LEXT 4000 laser scanning confocal microscope of ceramic sherd K1-5 from Kavewa, Fiji at a magnification of 108x.

Arrows represent length (horizontal) and width (vertical) measurements of a single dentate tooth impression.

Source: Kathleen LeBlanc. 


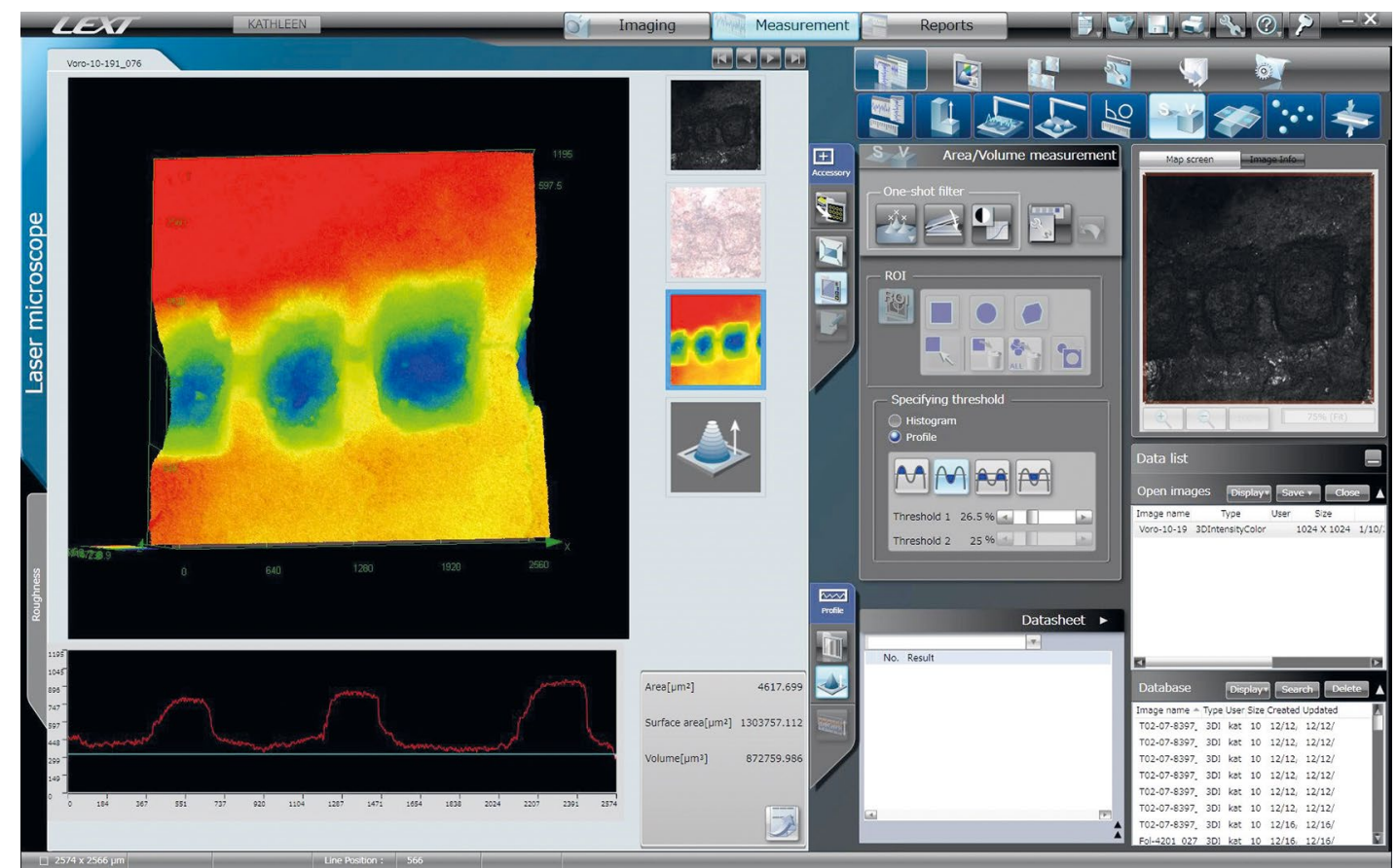

Figure 14.3. Image generated from 0lympus LEXT 4000 of ceramic sherd Voro10:191 from Vorovoro, Fiji magnified at $108 x$.

Colours represent differential depth measurements, which can be accurately measured through the corresponding software, as seen in the bottom left corner.

Source: Kathleen LeBlanc.

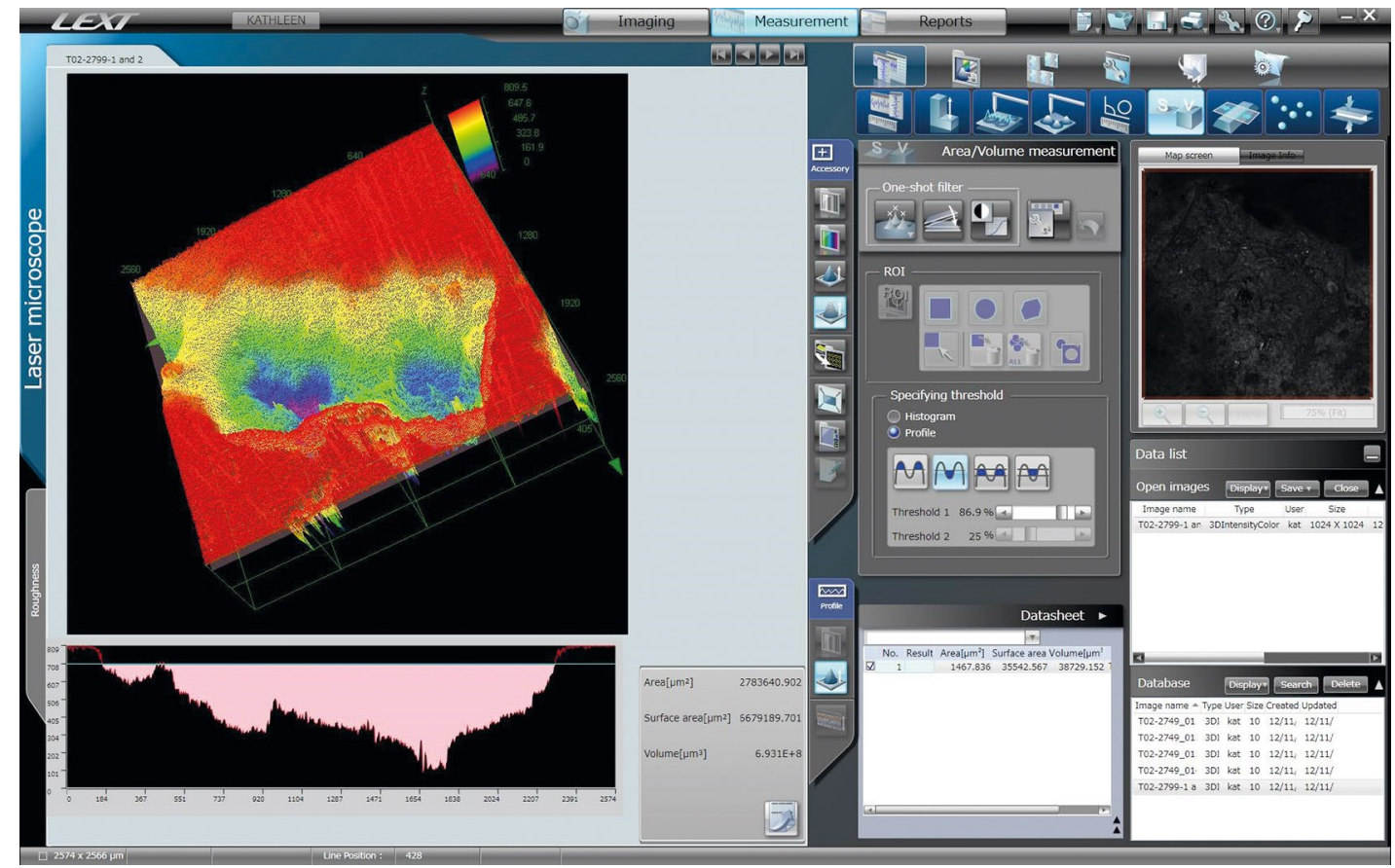

Figure 14.4. Image generated from Olympus LEXT 4000 of ceramic sherd To2-2749 from Nukuleka, Tonga. Through corresponding software, the area, surface area and volume of a given dentate-stamped tooth can be measured, as shown in the bottom left corner.

Source: Kathleen LeBlanc. 


\section{Nominal attributes}

Although the measurement of design application is an important part of a structural approach, such an approach is not complete without analysis of the nominal attributes that are specific to the study region. Despite concerns raised over the recording and description of design elements and motifs, particularly within the Eastern Lapita region, such aspects of design are an important part of a comprehensive structural approach. They are also an aspect of design that needs to be compared to structural variables to parse out difference, if any, in transmission mechanisms. For this reason, the analysis of elements and motifs are included here, along with the identification of the processes applied to elements (Table 14.1). Aside from traditional recording of elements and motifs, a structural approach should also include attributes that describe the layout of design fields, as well as parameters that are specific to a design repertoire. In the case of Lapita ceramics, the structural approach used here includes the recording of the direction of vessel zones, symmetry notation, presence/absence of lime filling, infilling of motifs and slip.

Elements and motifs were recorded based on previously compiled lists for the Lapita region and were identified according to the most recent coding system developed by Chiu and Sand (2005). A limitation with this system is that it does not consider the direction of element application. For instance, element six is a dentate-stamped curve (Chiu and Sand 2005:138). This definition does not indicate where the inflection point on the curve is positioned, either north, south, east or west. ${ }^{1}$ The direction impacts how the recorder views the element. For this reason, the Chiu and Sand (2005) notation system required modification to reflect changes in element direction (Table 14.2). Motif codes were based on previous motif lists collected specifically for the region under study. The Poulsen (1987) list was consulted first for consistency. If a motif could not be identified by this system, then Mead and/or Anson lists were consulted (Anson 1983; Mead et al. 1975). To increase comparability across sites, element, motif and process type were recorded once per sherd and Poulsen's (1987) motif categories were simplified into letter categories. For example, a motif labelled A4 or H3 in Poulsen's (1987) motif code was here labelled as motif A or $\mathrm{H}$, respectively. To describe how elements are combined to form motifs, Sharp's (1988) notation system was used. This system requires the recorder to identify the processes, or movements, that express the relationships between elements and motifs as outlined in Sharp (1988). Processes include such movements as repetition, half-drop mesh and mirror-reflection, among others (Figure 14.5).

Table 14.2. Extension and variation on Lapita design elements outlined in Chiu and Sand (2005). These are used to construct structural rules as outlined in Sharp (1988).

\begin{tabular}{|l|l|l|}
\hline Shape & Design element & Code \\
\hline Straight horizontal & Dentate stamped & 1.1 \\
& Impressed & 2.1 \\
& Appliqué & 21.1 \\
& Rouletted & 22.1 \\
\hline Straight vertical & Dentate stamped & 1.2 \\
& Impressed & 2.2 \\
& Appliqué & 21.2 \\
& Rouletted & 22.2 \\
\hline Straight angled in a NE direction & Dentate stamped & 1.3 \\
& Impressed & 2.3 \\
& Appliqué & 21.3 \\
& Rouletted & 22.2 \\
\hline
\end{tabular}

1 In this context, north refers to the top of a sherd, south refers to the bottom of a sherd, east refers to the right side of a sherd and west refers to the left side of a sherd. 


\begin{tabular}{|c|c|c|}
\hline Shape & Design element & Code \\
\hline Straight angled in a SE direction & $\begin{array}{l}\text { Dentate stamped } \\
\text { Impressed } \\
\text { Appliqué } \\
\text { Rouletted }\end{array}$ & \begin{tabular}{|l|}
1.4 \\
2.4 \\
21.4 \\
22.4
\end{tabular} \\
\hline Straight angled in a SW direction & $\begin{array}{l}\text { Dentate stamped } \\
\text { Impressed } \\
\text { Appliqué } \\
\text { Rouletted }\end{array}$ & $\begin{array}{l}1.5 \\
2.5 \\
21.5 \\
22.5\end{array}$ \\
\hline Straight angled in a NW direction & $\begin{array}{l}\text { Dentate stamped } \\
\text { Impressed } \\
\text { Appliqué } \\
\text { Rouletted }\end{array}$ & $\begin{array}{l}1.6 \\
2.6 \\
21.6 \\
22.6\end{array}$ \\
\hline Curved horizontal inflection point north & $\begin{array}{l}\text { Dentate stamped } \\
\text { Impressed } \\
\text { Appliqué } \\
\text { Rouletted curved } \\
\end{array}$ & \begin{tabular}{|l|}
6.1 \\
2.7 \\
2.1 .7 \\
22.7 \\
\end{tabular} \\
\hline Curved horizontal inflection point south & $\begin{array}{l}\text { Dentate stamped } \\
\text { Impressed } \\
\text { Appliqué } \\
\text { Rouletted }\end{array}$ & \begin{tabular}{|l|}
6.2 \\
2.8 \\
21.8 \\
22.8
\end{tabular} \\
\hline Curved vertical inflection point east & $\begin{array}{l}\text { Dentate stamped } \\
\text { Impressed } \\
\text { Appliqué } \\
\text { Rouletted } \\
\end{array}$ & \begin{tabular}{|l|}
6.3 \\
2.9 \\
21.9 \\
22.9 \\
\end{tabular} \\
\hline Curved vertical inflection point west & $\begin{array}{l}\text { Dentate stamped } \\
\text { Impressed } \\
\text { Appliqué } \\
\text { Rouletted } \\
\end{array}$ & \begin{tabular}{|l|}
6.4 \\
2.10 \\
21.10 \\
22.10 \\
\end{tabular} \\
\hline Circle & Appliqué circle (if single) & 21.11 \\
\hline Square & Appliqué square (if single) & 21.12 \\
\hline Appliqué & Appliqué & 21 \\
\hline Roulette & Roulette & 22 \\
\hline
\end{tabular}

Source: Table compiled by Kathleen LeBlanc, after Chiu and Sand (2005); Sharp (1988).

The direction of vessel zone was recorded here to first identify if a sherd had evidence of zone patterning and, if so, to describe if that zone was positioned either horizontally, vertically, or showed evidence of both (Figure 14.6). To further describe the layout of design, symmetry notation was recorded. Symmetry, as it is used here, refers to the motion of motif repetition. The notation system used is that of Washburn and Crowe (1988), who have produced a handbook of standard procedures to follow when analysing symmetry. By following the flowcharts provided in the handbook, the researcher can easily determine the four-symbol code that best describes a given symmetrical pattern, offering a relatively objective way in which to analyse designs that can easily be repeated and applied cross-culturally. Aside from zone direction and symmetry, there are three attributes that relate specifically to the Lapita design repertoire: lime filling, motif infilling and slip. The presence of lime and slip was based on visual inspection. The presence of motif infilling was determined by consulting motif list inventories to find the appropriate motif and then determining, based on visual inspection, if additional elements were added within the motif. 


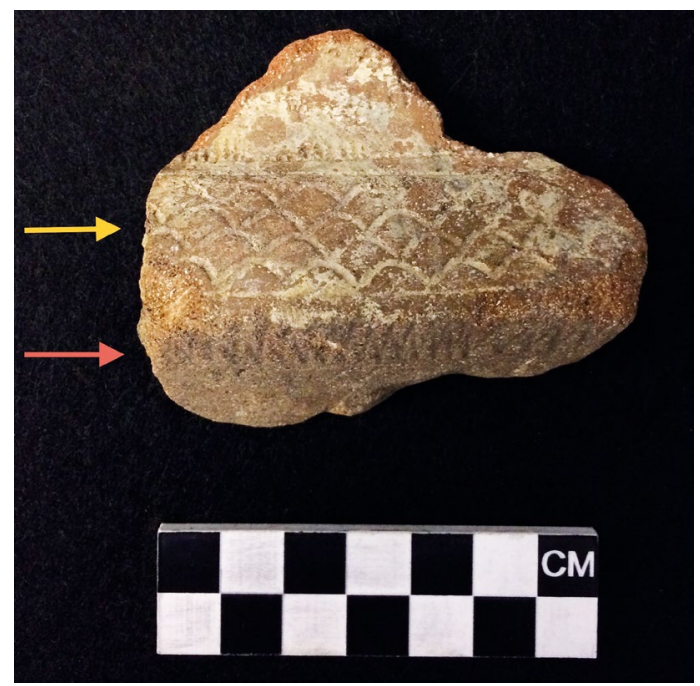

Figure 14.5. Sherd from the Lapita site (WK0013A) in New Caledonia.

Orange arrow indicates the process of half-drop mesh, while the red arrow represents the process of repetition. Both represent the process of intersection because there is no visible space between elements.

Source: Kathleen LeBlanc.

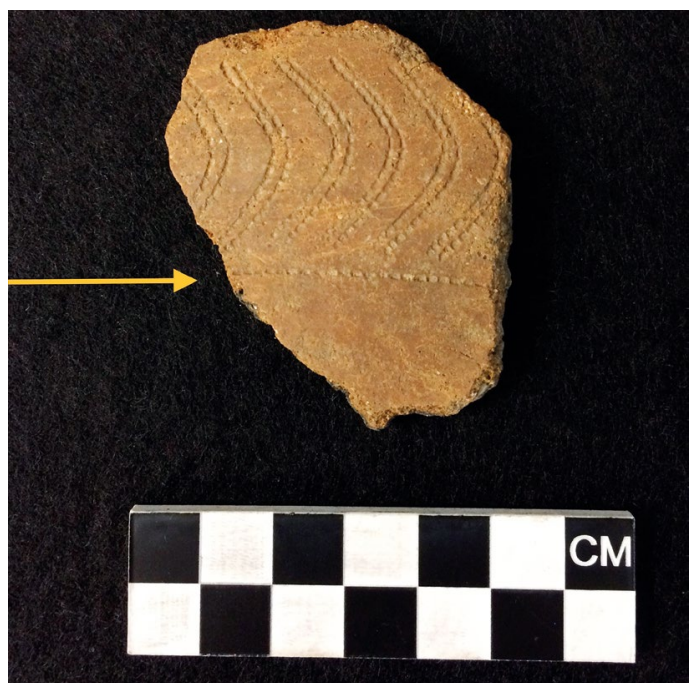

Figure 14.6. Sherd 221 from the Lapita site (WK0013A) in New Caledonia.

The design zone is separated into two horizontal zones by a single horizontal dentate-stamped line as indicated by the arrow.

Source: Kathleen LeBlanc.

\section{Archaeological ceramic assemblages}

This study builds upon LeBlanc's earlier research (2016a), which focused on design analysis within the Eastern Lapita region. Here, the approach is expanded to encompass a wider Lapita area using sherd samples from three Lapita Provinces: Eastern, Western and Southern. When possible, sites for which reliable dates were available were chosen, along with areas within sites that were less likely to have been disturbed. Once identified, 25 sherds in total for each Lapita Province were sampled for use with the Leica. Ten sherds were selected from the original sample of 25 in each Lapita Province for use with the LEXT, based upon their size and shape suitability.

The sampling procedure followed was random sampling for collections held at Simon Fraser University and a grab sample from collections held elsewhere. To be deemed appropriate for analysis, each sherd had to have at least four lines of clearly visible dentate-stamped impressions. These samples were then analysed for the attributes indicated above.

The Eastern Lapita Province was organised into four sample categories: Early Tonga, Late Tonga, West Fiji and East Fiji (Figure 14.7). These categories were chosen to analyse both spatial and temporal homogeneity/heterogeneity. Precise dating from coral branch files within Tonga enable sites to be categorised into Early and Late groups (Burley et al. 2012, 2015). The same cannot be said for Fiji, where dating techniques and results are the subject of ongoing debate (Burley et al. 2012; Nunn and Petchey 2013). For this reason, Fiji is divided into west and east variants here to determine if ceramic design from East Fiji aligns more with sherds from West Fiji or Tonga. Sherds from several archaeological sites were included in each sample (Table 14.3). From these, 25 sherds were randomly selected for each sample. ${ }^{2}$

2 Aside from the sites of Bourewa, Naigani and Lakeba, which were sampled outside of Simon Fraser University under timeconstrained circumstances. 


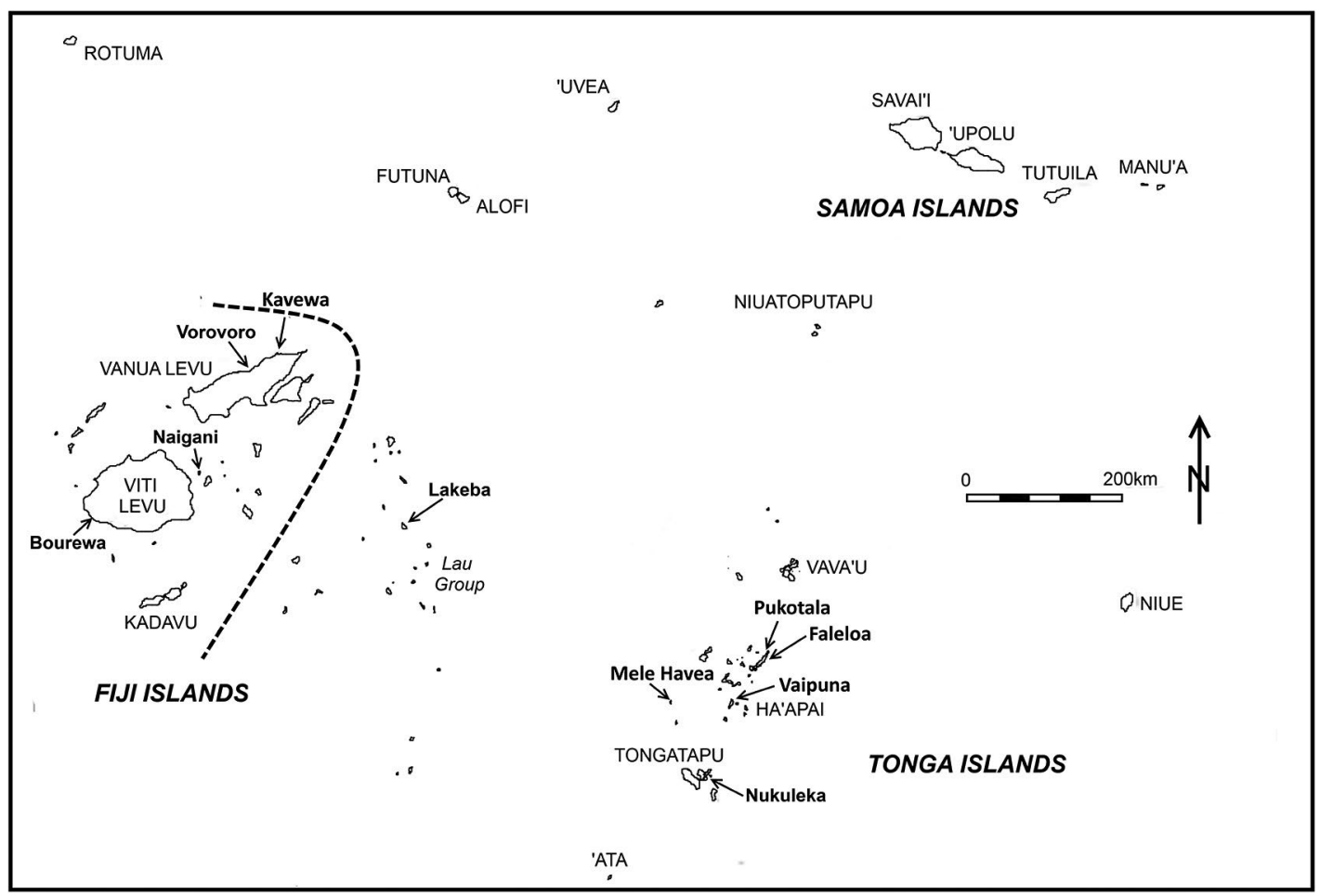

Figure 14.7. Island groups included in the Eastern Lapita Province.

Arrows indicate archaeological sites analysed in this study.

Source: Kathleen LeBlanc.

Table 14.3. Sample size used for the Eastern Lapita Province for analysis with the Leica and LEXT microscopes.

\begin{tabular}{|l|l|l|l|l|}
\hline $\begin{array}{l}\text { Ceramic } \\
\text { sample }\end{array}$ & Archaeological sites & $\begin{array}{l}\text { N ceramic sherds } \\
\text { analysed with Leica }\end{array}$ & $\begin{array}{l}\text { Sampling } \\
\text { strategy }\end{array}$ & $\begin{array}{l}\text { N ceramic sherds } \\
\text { analysed with LEXT }\end{array}$ \\
\hline Early Tonga & Nukuleka (Burley et al. 2010) & 25 & random & 10 \\
\hline Late Tonga & Pukotala (Burley 1998; Burley et al. 1999) & 5 & random & 2 \\
\hline & Faleloa (Burley 1998; Burley et al. 1999) & 5 & random & 2 \\
\hline & Vaipuna (Burley 1998; Burley et al. 1999) & 5 & random & 2 \\
\hline & Mele Havea (Burley 1998; Burley et al. 1999) & 5 & random & 2 \\
\hline & Tongoleleka (Burley 1998; Burley et al. 1999) & 5 & random & 2 \\
\hline West Fiji & Bourewa (Nunn and Petchey 2013) & 7 & grab & 2 \\
\hline & Kavewa & 5 & random & 2 \\
\hline & Vorovoro (Burley 2012) & 5 & random & 2 \\
\hline & Naigani (Irwin et al. 2011) & 8 & grab & 4 \\
\hline East Fiji & Lakeba, site 196 (Wakea) (Best 1984) & 25 & grab & 10 \\
\hline
\end{tabular}

Source: Table prepared by Kathleen LeBlanc. See references within.

For Early Tonga, all 25 sherds come from the earliest founding settlement site of Nukuleka (2846-2830 cal. BP) (Burley et al. 2012, 2015). Ceramics were sampled from the 2007 excavation assemblage (Burley et al. 2010). From the 25 sherds that were sampled, 10 were chosen for use with the LEXT, based on size and shape suitability. For Late Tonga, all sherds come from one of five sites on the island group of Ha'apai: Tongoleleka, Mele Havea, Vaipuna, Faleloa and Pukotala. Sites within this region were settled after initial migration to Nukuleka, within approximately 70-90 years, and represent ceramic change within three to four generations of 
initial landfall in Tonga (Burley et al. 2015). Sites consist of single hamlet-sized occupations situated on back beach flats on the leeward coast of coral limestone islands (Burley et al. 1999). The earliest sites are Tongoleleka (2780-2660 cal. BP (CAMS 34561)) and Vaipuna (2740$2640 \mathrm{cal}$. BP (CAMS 41526)), situated on Lifuka Island and 'Uiha Island, respectively. The three later sites include Faleloa (2650-2550 cal. BP (CAMS 41530)) on Foa Island, Pukotala (27002580 cal. BP (CAMS 41516)) on Ha'ano Island, and Mele Havea (2690-2590 cal. BP (CAMS 41520)) on Ha'afeva Island (Burley et al. 2015). Five sherds that had at least four lines of clearly visible dentate stamping were randomly sampled from each site for use with the Leica, for a total of 25 sherds. For the LEXT, two sherds from each site were selected, for a total of 10 sherds, based on shape and size suitability.

The East Fiji sample is composed of 25 ceramic sherds from the site of Wakea on the island of Lakeba in the Lau Group of islands (Best 1984). Sherds from Lakeba were sampled from the University of Auckland. This site was chosen because it is thought to represent the earliest settlement in East Fiji, dated to approximately $2850 \mathrm{cal}$. BP, and provides the least disturbed context of all sites within this region (Best 1984). Lau's ceramic sequence follows that in Tonga until 2100 BP, after which ceramic form and decoration aligns with West Fiji (Burley 2013). Linguistic reconstruction also supports this shift (Geraghty 1983). Aside from ceramic similarity, obsidian and adze fragments in Lau have been sourced to Tonga (Burley 2013). In the earliest sites, iron oxide and temper from Vanua Levu, along with adze fragments sourced to somewhere on the island of Viti Levu point to the possibility of early interaction between West and East Fiji or the settlement of East Fiji directly from West Fiji. Linguistic and genetic evidence tends to support the latter possibility, although early interaction cannot yet be ruled out. Comparison of ceramics from East Fiji with those from West Fiji and Tonga should help to determine if interaction post-settlement seems plausible for this region.

West Fijian sherds come from one of four sites: Bourewa, Naigani, Vorovoro and Kavewa. Bourewa is located on the Rove Peninsula in south-western Viti Levu. It is one of the earlier Lapita sites in Fiji, with initial settlement dated to 2841-2791 cal. BP (Nunn and Petchey 2013). Sherds were chosen as a representative grab sample from the Fiji Museum. Thirty sherds were hand selected, based on the criteria that they had at least four lines of clearly visible dentate stamping. From these 30 sherds, seven were randomly selected for use in this study. Recent excavations at the northern Fijian sites of Vorovoro and Kavewa suggest early and contemporaneous settlement with initial dates that are comparable to those for Bourewa. Both sites are situated off the northeast coast of Vanua Levu, with dentate-stamped ceramics indicative of early settlement in the region (Burley 2012; Burley et al. this volume). For both Vorovoro and Kavewa, five sherds each were randomly selected from the excavation catalogue and chosen for analysis if there were at least four lines of dentate stamping present.

One issue with the above samples from East and West Fiji is that they differ temporally, making direct comparisons difficult. To address this issue, sherds from the West Fiji Lapita site of Naigani, situated on the eastern side of Naigani Island off the eastern coast of Viti Levu, were sampled from the University of Auckland. Thirty samples were selected as a grab sample, ensuring that each had at least four lines of dentate stamping. From these 30, eight were randomly selected for use in this study. Settlement at Naigani dates to approximately $2850 \mathrm{cal}$. BP and is contemporaneous with Lakeba (Irwin et al. 2011). Preliminary testing of Naigani sherds with those from Bourewa, Kavewa and Vorovoro indicates that structural attributes do not differ significantly. Given this, Naigani was included in the West Fiji sample to decrease the probability that any attribute differences between West and East Fiji would be due to temporal factors. From the 25 West Fiji sherds used for analysis with the Leica, 10 were selected for analysis with the LEXT, based on shape and size suitability. 
Samples from the Western and Southern Lapita Provinces, as they are currently defined, were sought from two sites. The Western Lapita Province, east of the Bismarcks, represents the region around the Reefs-Santa Cruz to Vanuatu and is distinguished from the Far Western Lapita Province by less elaborate decoration and a decrease in the range of vessel forms (Spriggs 1997:70). The Southern Lapita Province is represented by Lapita sites found throughout New Caledonia (Sand 2000, 2010; Sand et al. 2011). This is differentiated from other provinces by the presence of stylised dentate-stamped faces on carinated pots and flat-bottomed dishes (Sand 2000:26).

The Western Lapita Province is represented by a sample of 25 ceramic sherds from the site of Teouma, located on Efate Island, central Vanuatu. Teouma is considered to be an early colonising Lapita site, with occupation likely occurring by $2940-2870$ cal. BP and ending around 2870 $2750 \mathrm{cal}$. BP (Petchey et al. 2015). The site was occupied during the same time as initial landfall in Tonga (2850-2830 cal. BP) and West Fiji (3020-2860 cal. BP). This site's close geographic and temporal proximity to Fiji makes it an ideal assemblage to compare to samples from the Eastern Lapita Province. Sherds were selected as a grab sample from excavations that took place between 2004 to 2010 (Bedford et al. 2010). From the 25 sherds used for analysis with the Leica, 10 were selected for analysis with the LEXT, based on shape and size suitability.

The sample from the Southern Lapita Province comprised 25 sherds chosen as a grab sample from Site WKO013A, the Lapita type-site. Dates for this site are the earliest in the Province, at c. 3000-2750 BP (Sand et al. 2011). The dates for the site are well within the range of initial occupation for West Fiji, East Fiji and Tonga. Sherds from WKO013A were selected from the 1995 excavation assemblage (Sand 1995). From the 25 sherds used for analysis with the Leica, 10 were selected for analysis with the LEXT, based on shape and size suitability.

\section{Statistical analysis}

Statistical methods were used to compare diversity/homogeneity in attribute distribution within and between sample regions and to determine the impact of sherd size and dentate density in relation to other categorical attributes. Variation in distribution of continuous attributes was analysed using ANCOVA (analysis of covariance). Normality was accessed by observation of histograms of attribute distribution and residuals to determine if ANOVA (analysis of variance) or the nonparametric alternative, K-W, was the more appropriate test. Post-hoc tests were then performed to determine where differences, if any, existed. ANOVA was also used to determine if attribute variation is greater within or between assemblages, in order to understand how variation differs among attributes, especially between those categorised as structural versus element-motif. Given the large number of post-hoc tests performed, it was determined that the value at which statistical significance is determined be adjusted. The Benjamini-Hochberg method was used here because it is less conservative than the Bonferroni method and has greater power (Benjamini 2010; Benjamini and Hochberg 1995).

It was reasoned that the density of design application could influence the size, shape and application of individual dentate tooth impressions. Based on this logic, the relationship between dentate density and each attribute was first assessed through a bivariate linear fit regression model. If a statistically significant relationship existed, then density was modelled as a covariate to control for its impact on the following attributes: dentate length, width, spacing 1 and spacing 2, depth, volume, area and surface area. Along with dentate density, the size of each sherd, as indicated through length and width measurements, was also used as a covariate in the model, where appropriate, to control for impact on dentate size and shape outcomes. 
Elements, motifs and processes between groups were analysed using frequency counts and assessed through comparison of contingency tables. Fischer's Exact test was used to assess the significance between groups. However, due to violation of the assumption of independence of observations, such results must be interpreted with caution. All other categorical variables, including lime filling, motif infilling, direction of vessel zone and symmetry, were compared using Fischer's Exact test. Statistical tests were performed using either JMP ${ }^{\circledR} 11$ or SPSS 22. See LeBlanc (2016a) for sherd attribute data.

\section{Results}

Before comparing continuous attribute distribution between groups, the relationship between attributes and dentate density, sherd length and sherd width was first accessed through bivariate linear fit regression models. Results indicate that for Leica attributes, density is a significant predictor of dentate width, length, spacing 1 and spacing 2 (Table 14.4). Density is therefore modelled as a covariate for Leica attributes. For LEXT attributes, the predictive significance of potential covariates differs for each attribute (Table 14.4). For dentate length, depth, area and volume, density is a significant predictor and is therefore controlled for as a covariate. For dentate surface area, none of the potential covariates have predictive significance, and for dentate width, sherd length and sherd width are significant predictors and are controlled for as covariates.

Histograms for attribute distributions were viewed to access data normality. For Leica attributes, dentate density and dentate spacing 2 required a natural log transformation, all other histograms were normally distributed. For LEXT attributes, dentate density, dentate width, surface area and volume required a natural log transformation, all other histograms were normally distributed.

Before running the ANCOVA model for Leica attributes, the distribution of density between groups was first accessed. Results from ANOVA indicate that dentate density differs significantly between groups $(p=0.0001)$. Post-hoc tests indicate that the only samples that do not differ are Early Tonga and East Fiji, Late Tonga and East Fiji, New Caledonia and Early Tonga, and Vanuatu and West Fiji (Appendix 14.1: Table 14A.1).

Table 14.4. $p$ values derived from bivariate linear fit regression between dentate density, sherd width and length with Leica and LEXT attributes for the Eastern, Southern and Western Lapita sample groups.

\begin{tabular}{|l|c|c|c|}
\hline Attributes & Dentate density & Sherd length & Sherd width \\
\hline Leica MZ6 & "0.001 & 0.4991 & 0.1812 \\
\hline Dentate length & 0.001 & 0.6346 & 0.2328 \\
\hline Dentate width & 0.002 & 0.6532 & 0.7683 \\
\hline Dentate spacing 1 & 0.001 & 0.3553 & 0.6109 \\
\hline Dentate spacing 2 & 0.8048 & 0.0245 & 0.0015 \\
\hline LEXT 4000 & 0.0001 & 0.7913 & 0.7519 \\
\hline Dentate width & "0.0345 & 0.1599 & 0.1816 \\
\hline Dentate length & $" 0.0028$ & 0.5102 & 0.6960 \\
\hline Dentate depth & 0.2767 & 0.3365 & 0.9426 \\
\hline Dentate area & $" 0.0005$ & 0.9825 & 0.5939 \\
\hline Dentate surface area & &
\end{tabular}

Asterisk indicates statistical significance at $\alpha=0.05$. Significance indicates that the covariate is a significant predictor of dentate attributes and must be controlled for in subsequent analysis.

Source: Table prepared by Kathleen LeBlanc. 
ANCOVA indicates that the distribution of all Leica MZ6 attributes differ significantly between groups, while controlling for dentate density (Table 14.5). Post-hoc tests indicate where differences lie (Appendix 14.1: Table 14A.2). For dentate length, Early Tonga, Late Tonga and East Fiji differ from all groups, but East Fiji and Late Tonga do not differ from each other; all other sample comparisons differ significantly. For dentate width, Late Tonga and East Fiji differ from all groups, except from each other; all other sample comparisons do not differ significantly. For spacing 1, the only significant difference between groups is for West Fiji and East Fiji, East Fiji and New Caledonia, and East Fiji and Vanuatu; all other sample comparisons are not significantly different. For spacing 2 , there are no significant differences between groups. The F-ratio obtained from each attribute comparison is above 1, indicating that there is more difference between than within groups (Table 14.5).

Table 14.5. $p$ values derived from comparisons of means between the Eastern, Southern and Western Lapita sample groups using ANCOVA.

\begin{tabular}{|l|c|c|c|c|}
\hline Leica MZ6 attributes & Dentate length & Dentate width & Dentate spacing 1 & Dentate spacing 2 \\
\hline$p$ value & $" 0.0001$ & 0.0001 & $" 0.0001$ & $" 0.0001$ \\
\hline F-ratio & 22.9848 & 8.2675 & 5.6202 & 9.0727 \\
\hline
\end{tabular}

Asterisk indicates statistical significance at $\alpha=0.05$.

Source: Table prepared by Kathleen LeBlanc.

The distribution of all LEXT 4000 attributes indicates that dentate width does not differ significantly between samples; all other attributes differ significantly, as determined through ANCOVA (Table 14.6). Post-hoc tests indicate where differences lie (Appendix 14.1: Table 14A.3). For dentate volume and depth, none of the sample comparisons are significantly different. For dentate length, Early Tonga differs from West Fiji and Vanuatu, Late Tonga differs from West Fiji, New Caledonia and Vanuatu, and East Fiji differs from West Fiji, New Caledonia and Vanuatu. For dentate area, West Fiji differs from each group, East Fiji differs from New Caledonia and Vanuatu, and New Caledonia and Vanuatu differ from each other; no other sample comparisons differ significantly. For dentate surface area, West Fiji and Vanuatu differ from all groups and New Caledonia and East Fiji also differ; no other sample comparisons differ significantly.

Table 14.6. $p$ values derived from comparisons of means between the Eastern, Southern and Western Lapita sample groups using ANCOVA.

\begin{tabular}{|l|c|c|c|c|c|c|}
\hline LEXT attributes & Dentate width & Dentate length & Dentate depth & Dentate area & $\begin{array}{c}\text { Dentate } \\
\text { surface area }\end{array}$ & $\begin{array}{c}\text { Dentate } \\
\text { volume }\end{array}$ \\
\hline$p$ value & 0.0520 & 0.0001 & 0.0220 & $" 0.0002$ & 0.0001 & $" 0.0149$ \\
\hline F-ratio & 2.1713 & 11.0097 & 2.7274 & 5.4217 & 25.8678 & 2.9412 \\
\hline
\end{tabular}

Asterisk indicates statistical significance at $\alpha=0.05$.

Source: Table prepared by Kathleen LeBlanc.

For the nominal variables of symmetry, lime filling, zone direction and infilling of motifs, only lime filling does not differ between groups; all other attributes differ significantly as indicated through Fischer's Exact test (Table 14.7). Post-hoc tests indicate where differences lie (Appendix 14.1: Table 14A.4). For symmetry, New Caledonia differs from all groups, and East Fiji and Late Tonga both differ from Vanuatu; no other sample comparisons differ significantly. For zone direction, Vanuatu differs from each group; no other sample comparisons differ significantly. For motif infilling, Early Tonga differs from Late Tonga, West Fiji and Vanuatu, Late Tonga differs from all groups except East Fiji, and East Fiji differs from West Fiji, New Caledonia and Vanuatu. 
Table 14.7. $p$ values derived from Fischer's Exact test to determine the significance of association between attributes and ceramic sherds from the Eastern, Southern and Western Lapita sample groups.

\begin{tabular}{|l|c|c|c|c|}
\hline Categorical attributes & Lime filling & Symmetry & Direction of vessel zone & Motif infilling \\
\hline$\rho$ value & 0.411 & 0.000 & $" 0.000$ & $" 0.000$ \\
\hline
\end{tabular}

Asterisk indicates statistical significance at $\alpha=0.05$.

Source: Table prepared by Kathleen LeBlanc.

For the analysis of elements, motifs and processes, both the number per sherd and frequency were compared between groups. For the number of elements, motifs and processes per sherd, the distribution of attributes was first accessed through observation of histograms. The number of motifs per sherd are not normally distributed, but the residuals are; all other attributes are normally distributed. Before comparing attribute distribution between groups through ANCOVA, the relationship between attributes and dentate density, sherd width and sherd length was determined through a bivariate linear fit regression model. Results indicate that density, sherd width and sherd length are significant predictors for the number of elements-motifs-processes per sherd and are therefore controlled for during ANCOVA (Table 14.8). ANCOVA indicates that the number of elements ( $p=0.0001)$, motifs $(p=0.0001)$ and processes $(p=0.0022)$ per sherd differ significantly between groups. However, post-hoc tests, with adjusted significance levels determined by the Benjamini-Hochberg method, reveal that none of the comparisons between samples differ significantly.

Table 14.8. $p$ values derived from bivariate linear fit regression between dentate density, sherd length, sherd width and the number of elements-motifs-processes per sherd for the six Lapita samples.

\begin{tabular}{|l|c|c|c|}
\hline Attributes & Dentate density & Sherd width & Sherd length \\
\hline Elements-Sherd & "0.0001 & $" 0.0023$ & $" 0.0005$ \\
\hline Motifs-Sherd & 0.0440 & $" 0.0001$ & 0.0001 \\
\hline Processes-Sherd & $" 0.0063$ & $" 0.0015$ & $" 0.0002$ \\
\hline
\end{tabular}

Asterisk indicates statistical significance at $\alpha=0.05$. Significance indicates that dentate density, sherd width and sherd length are significant predictors of attributes and must be controlled for in subsequent analysis.

Source: Table prepared by Kathleen LeBlanc.

Using Fischer's Exact test, the frequency of elements $(p=0.000)$, motifs $(p=0.000)$ and processes $(p=0.000)$ vary between groups. Individual Fischer's Exact tests between each group pair indicate which samples differ (Appendix 14.1: Table 14A.5). For element frequency, the only samples that do not differ are Early Tonga, Late Tonga and East Fiji, along with West Fiji and New Caledonia. For motif frequency, Late Tonga does not differ from any group except for Vanuatu; all other sample comparisons differ significantly. For process frequency, New Caledonia differs from Early Tonga, East Fiji and Vanuatu; no other sample comparisons differ significantly. However, given that element, motif and process frequency are calculated by recording more than one observation per sherd, the assumption of independence is violated for Fischer's Exact test. Results, therefore, must be interpreted with caution. For this reason, contingency tables are provided as an additional medium for comparing sample groups (Appendix 14.1: Tables 14A.6, 14A.7 and 14A.8). 


\section{Discussion}

The above results indicate that regions within the Eastern Lapita Province share similarities with the west and south. West Fiji is differentiated from East Fiji-Tonga based on greater similarity to outside samples than to those within the Eastern Lapita Province. Based on this, the null hypothesis:

The distribution of elements-motifs and structural attributes of Lapita design do not vary between the Eastern, Western and Southern Lapita Provinces.

is rejected. Assemblages from West Fiji, East Fiji, Early Tonga, Late Tonga, Vanuatu and New Caledonia do differ significantly to varying degrees for the attributes analysed here. Discrepancy exists between structural versus element-motif attributes, which may be due to limited sample size, or may suggest difference in the way design is selected and subsequently applied to a vessel surface. Regardless of the reason, this study reaffirms the conclusion from LeBlanc (2016b) that the Eastern Lapita Province is not a cohesive stylistic region, given differences in the way design is applied to the vessel surface.

Results for continuous attributes indicate that density is a significant predictor of Leica attributes and most LEXT attributes, aside from surface area and width. Dentate density, sherd length and sherd width are also significant predictors of the number of elements, motifs and processes per sherd. This has important implications for Lapita design analysis. Given that these variables play a role in predicting the size and shape of dentate stamping, along with the frequency of elements, motifs and processes, they should be incorporated as covariates for comparison of both structural and element-motif attributes between regions. Aside from being a predictor of attributes, dentate density differs significantly between groups. However, there is no difference between East Fiji and Early Tonga - Late Tonga, Early Tonga - New Caledonia, and Vanuatu - West Fiji. This suggests that East Fiji - Late Tonga have designs that are less densely applied than for New Caledonia Early Tonga or Vanuatu - West Fiji.

All Leica attributes differ significantly between groups. However, post-hoc comparisons indicate that, for spacing 2, there are no significant differences between groups, which is likely due to the fact that density is controlled. The general trend is that East Fiji and Late Tonga are most similar, whereas West Fiji is more similar to New Caledonia and Vanuatu. Early Tonga also shares some similarity in attribute distribution with New Caledonia.

For LEXT attributes, only dentate length, area and surface area differ between groups. Overall, results for continuous variables indicate that Early Tonga - New Caledonia, along with East Fiji - Late Tonga are most similar. West Fiji is also similar to Vanuatu, aside from area measurements. The greatest differences occur when East Fiji is compared to New Caledonia, Vanuatu and West Fiji, and when West Fiji is compared to Late Tonga.

The categorical variables of symmetry, zone direction and motif infilling differ significantly between groups, but lime filling does not. For symmetry, New Caledonia differs from all groups, and for zone direction, Vanuatu differs from all groups. This may suggest that these attributes developed in isolation after initial settlement or may reflect small sample and sherd size used for analysis. Motif infilling suggests that Early Tonga is most similar to New Caledonia and East Fiji; West Fiji is most similar to New Caledonia and Vanuatu; and East Fiji is most similar to Early and Late Tonga. This could potentially signal interaction between Early Tonga - New Caledonia and between West Fiji - New Caledonia - Vanuatu. East Fiji and Early and Late Tonga also show evidence of potential interaction. However, it is equally likely that this patterning may represent common ancestry or temporal variation. 
The number of elements, motifs and processes per sherd differ. However, post-hoc comparisons indicate that none of the comparisons are statistically significant. Element, motif and process frequency, however, do differ significantly between groups. Aside from element frequency, results appear to contradict, or at least not confirm, those for continuous attributes. This could be due to the likely effect that dentate density and sherd size have on these variables, highlighting the importance of controlling for both sherd size and dentate density in Lapita design analysis. A visual comparison of frequency tables provides more in common with results from structural analysis. For element frequency, West Fiji, New Caledonia and Vanuatu have the highest diversity and Early Tonga - West Fiji and West Fiji - Vanuatu share the greatest number of element types, although not by a large margin. For motif frequency, again, West Fiji, Vanuatu and New Caledonia appear the most diverse in terms of the number of motif types present in each assemblage. Here, Early Tonga - New Caledonia and West Fiji - Vanuatu - New Caledonia share the greatest number of motif types. Finally, process frequency appears most diverse for New Caledonia and Vanuatu, which makes sense given that these regions are generally assumed to have been settled before either West Fiji or East Fiji - Tonga (Petchey et al. 2015).

Structural attributes indicate that the Vanuatu sample almost always differs from East Fiji, Early Tonga and Late Tonga, while the New Caledonia sample almost always differs from East Fiji. This suggests that there is difference in the structural application of design between East Fiji - Early Tonga - Late Tonga and the west and, for several attributes, from the south as well. The difference between each region is greater than the difference within, as indicated through positive F-ratios above one. This suggests that regions are cohesive units; however, given that the Eastern Lapita Province is broken up into four separate regions, it is difficult to evaluate if it represents a cohesive Province from this measure. Post-hoc tests of structural attributes, however, would suggest otherwise.

Results from element-motif analysis are not clear-cut and do not consistently reaffirm the similarities/dissimilarities between groups as determined through structural attributes. This may suggest that these two aspects of design have different transmission histories. Alternatively, it may indicate that the methods that currently exist to identify and label elements and motifs require unification, as is currently being done for the Lapita region (Chiu and Sand 2005). Until such a system is in place, the question of how structural and element-motif attributes were passed within and between generations is difficult, if not impossible, to answer adequately.

Overall, results for this study provide a more complex picture of initial settlement and subsequent interaction within the Eastern Lapita Province. Based on initial comparison of both structural and element-motif attributes, both Early Tonga and West Fiji share design characteristics with New Caledonia and, to a more limited extent, Vanuatu. In total, West Fiji shares eight attributes with New Caledonia and 11 with Vanuatu. Early Tonga shares seven attributes with New Caledonia and four attributes with Vanuatu. East Fiji shares one attribute in common with New Caledonia, and Late Tonga shares two attributes in common with New Caledonia. These trends suggest that West Fiji and Early Tonga share common ancestry with potters from New Caledonia and Vanuatu (at least for West Fiji) and/or were settled from potters originating there. Alternatively, this pattern may be more indicative of temporal variation where West Fiji is settled first from the west and/or potentially the south and then potters quickly move eastwards towards Tonga. Following initial settlement, interaction between West Fiji and Tonga decreases. The placement of East Fiji within this scenario is more difficult to ascertain. Either potters from Tonga settled or interacted to a large extent with East Fiji or East Fiji was settled initially by potters moving eastwards from West Fiji and then interaction ceased and potters from East Fiji and Tonga subsequently interacted. The latter situation would seem to be the most logical given the linguistic and genetic data for the Eastern Lapita region discussed below. 
Linguistic research suggests that West and East Fiji interacted during initial settlement, with East Fiji potentially even settled from West Fiji (Geraghty 1983). However, soon after, there was a distinct break, at least linguistically, between western and eastern language variants. Eastern Fiji then underwent a 'period of common development' with languages ancestral to Polynesian languages, including those of Tonga (Geraghty 1983:348). Genetic evidence paints a more complex picture. Maternal DNA from mitochondria suggest that individuals from East Fiji are more genetically similar to Polynesian populations (i.e. Tongans) than individuals from West Fiji (Shipley et al. 2015). However, paternal DNA suggests that East Fijians are just as similar to Melanesians to the west as West Fijians. If sex-biased admixture took place during the Lapita period, as has been suggested by other genetic studies (Delfin et al. 2012) and potters were female, as has been argued for the Lapita period (Marshall 1985), it stands to reason that female potters from East Fiji were interacting, to varying degrees, with potters in Tonga and not with those in West Fiji. This hypothesis requires further testing, which could be aided by identifying transmission mechanisms through the analysis of both structural and element-motif attributes from assemblages derived from the regions analysed here.

In order to differentiate between the competing hypotheses outlined above, multiple lines of evidence need to be consulted, along with increased sample sizes and a database capable of recording structural and motif attributes in a standardised manner. Despite the current lack of a standardised approach to analysing Lapita design, the analysis presented here indicates that West Fiji is clearly differentiated from its eastern counterparts. The Eastern Lapita 'Province' requires redefinition.

\section{Conclusion}

This study has introduced a new structural approach to analysing Lapita design that differs from traditional element-motif analysis. The approach utilises microscopy techniques to quantify the density, layout and organisation of design. Four sample regions from within the Eastern Lapita Province are compared: West Fiji, East Fiji, Early Tonga and Late Tonga, along with a sample each from Vanuatu (Western Lapita Province) and New Caledonia (Southern Lapita Province). These regions are analysed to determine which differ significantly when compared via structural versus element-motif analysis. The main aim of this analysis was to determine the difference, if any, between methods and to understand if the Eastern Lapita Province represents a cohesive region in terms of ceramic design when compared to samples from the Western and Southern Lapita Provinces.

Results from structural analysis indicate that East Fiji (Lau) has more in common with Tonga than with West Fiji. Results from element-motif analysis suggest similar patterning, but they are problematic due to the influence of dentate density and sherd size on the frequency of elements and motifs. When samples from both the Southern and Western Lapita Province are added into the analysis, it appears that West Fiji is more similar to the southern and western samples than to East Fiji and Late Tonga, although there are some similarities with Early Tonga. These results suggest that East Fiji, Early Tonga and Late Tonga represent a separate interaction sphere from West Fiji that likely developed soon after initial settlement, potentially from the latter region. The same samples analysed solely with element-motif methods suggest relative homogeneity between groups. This is likely since this approach cannot isolate difference in the structural application of design. Such results indicate that both structural and element-motif analyses need further testing. Elements and motifs are no doubt important for the analysis of design, but structural application can and should be used as a complementary approach. 
The structural approach used here can quantify the complexity of design application in a way that is easily applied and compared both within and between cultural regions. By using microscopy techniques applicable to small ceramic sherds that form the bulk of Lapita archaeological assemblages, it is no longer a requirement that large sherds or even whole pots be present in order to undertake structural analysis. Both the element-motif and structural approach should be used to test hypotheses simultaneously so that archaeologists can determine the extent to which either method provides a useful account of interaction, or lack thereof, in the past. Increased sample sizes in future studies should help to reduce any statistical 'noise' due to the impact of tool form and potter skill level.

\section{Acknowledgements}

LeBlanc would like to thank David V. Burley and Mark Collard for contributing to the research design of this project as part of LeBlanc's PhD dissertation committee. The Vanuatu Cultural Centre, the Institute of Archaeology of New Caledonia and the Pacific, the Fiji Museum, Simon Best, Geoffrey Irwin and David V. Burley provided access to ceramic samples. The Advanced Materials and Process Engineering Laboratory at the University of British Columbia provided access to the LEXT 4000 and the Department of Archaeology at Simon Fraser University provided access to the Leica MZ6. Ian Bercovitz, Director of the Statistical Consulting Service at Simon Fraser University, provided essential guidance towards the statistical analyses used throughout this paper. Vienna Chichi Lam kindly assisted in figure preparations. LeBlanc wishes to thank the Social Sciences and Humanities Research Council of Canada and the Department of Archaeology at Simon Fraser University for providing funding to undertake this research. All figures and tables were produced by LeBlanc. An anonymous reviewer provided insightful comments on a previous draft.

\section{References}

Ambrose, W. 2007. The implements of Lapita ceramic stamped ornamentation. In S. Bedford, C. Sand and S.P. Connaughton (eds), Oceanic explorations: Lapita and Western Pacific settlement, pp. 213-221. Terra Australis 26. ANU E Press, Canberra. doi.org/10.22459/TA26.2007.

Anson, D. 1983. Lapita pottery of the Bismarck Archipelago and its affinities. Unpublished PhD thesis, University of Sydney, Sydney.

Arnold, D.E. 1983. Design structure and community organization in Quinua, Peru. In D. Washburn (ed.), Structure and cognition in art, pp. 1-7. Cambridge University Press, New York.

Bedford, S., M. Spriggs, H. Buckley, F. Valentin, R. Regenvanu and M. Abong 2010. A cemetery of first settlement: The site of Teouma, South Efate, Vanuatu. In C. Sand and S. Bedford (eds), Lapita: Ancêtres Océaniens/Oceanic ancestors, pp. 140-161. Museé du quai Branly and Somogy, Paris.

Benjamini, Y. 2010. Discovering the false discovery rate. Journal of the Royal Statistical Society: Series B (Statistical Methodology) 72(4):405-416. doi.org/10.1111/j.1467-9868.2010.00746.x.

Benjamini, Y. and Y. Hochberg 1995. Controlling the false discovery rate: A practical and powerful approach to multiple testing. Journal of the Royal Statistical Society: Series B (Statistical Methodology) 57(1):289-300. doi.org/10.1111/j.2517-6161.1995.tb02031.x.

Best, S. 1984. Lakeba: The prehistory of a Fijian island. Unpublished PhD thesis, University of Auckland, Auckland.

Burley, D.V. 1998. Tongan archaeology and the Tongan past, 2950-150 B.P. Journal of World Prehistory 12(3):337-392. doi.org/10.1023/A:1022322303769. 
Burley, D.V. 2012. Archaeological surveys of Kadavu, Vanua Levu and Viti Levu. Unpublished project report. Fiji Museum, Suva, Fiji.

Burley, D.V. 2013. Fijian polygenesis and the Melanesian-Polynesian divide. Current Anthropology 54(4):436-462. doi.org/10.1086/671195.

Burley, D.V. and K. LeBlanc 2015. Obfuscating migration and exchange: The misconceptions of an Eastern Lapita Province. In C. Sand, S. Chiu and N. Hogg (eds), The Lapita Cultural Complex in time and space: Expansion routes, chronologies and typologies, pp. 173-183. Archeologia Pacifika 4. Institut d'archéologie de la Nouvelle-Calédonie et du Pacifique (IANCP) Nouméa.

Burley, D.V., D.E. Nelson and R. Shutler Jr 1999. A radiocarbon chronology for the Eastern Lapita frontier in Tonga. Archaeology in Oceania 34(2):59-70. doi.org/10.1002/j.1834-4453.1999. tb00429.x.

Burley, D.V., A. Storey and J. Witt 2002. On the definition and implications of Eastern Lapita ceramics in Tonga. In S. Bedford, C. Sand and D.V. Burley (eds), Fifty years in the field. Essays in honour and celebration of Richard Shutler Jr's archaeological career, pp. 213-226. New Zealand Archaeological Association Monograph 25. New Zealand Archaeological Association, Auckland.

Burley, D.V., A. Barton, W.R. Dickinson, S.P. Connaughton and K. Taché 2010. Nukuleka as a founder colony for west Polynesian settlement: New insights from recent excavations. Journal of Pacific Archaeology 1(2):128-144.

Burley, D.V., M.I. Weisler and J.-x. Zhao 2012. High precision U/Th dating of first Polynesian settlement. PLoS One 7(11):e48769. doi.org/10.1371/journal.pone.0048769.

Burley, D., K. Edinborough, M. Weisler and J.-x. Zhao 2015. Bayesian modeling and chronological precision for Polynesian settlement of Tonga. PLoS One 10(3):e0120795. doi.org/10.1371/journal. pone.0120795.

Canouts, V. 1991. A formal approach to design: Symmetry and beyond. In R.L. Bishop and F.W. Lange (eds), The ceramic legacy of Anna O. Shepard, pp. 280-320. University Press of Colorado, Niwot.

Carlson, R.L. 1961. White mountain red ware: A stylistic tradition in the prehistoric pottery of East Central Arizona. The University of Arizona Press, Tucson.

Carson, M.T., H.-C. Hung, G.R. Summerhayes and P. Bellwood 2013. The pottery trail from Southeast Asia to Remote Oceania. The Journal of Island and Coastal Archaeology 8(1):17-36. doi.org/10.1080/ 15564894.2012.726941.

Chiu, S. 2003. The socio-economic functions of Lapita ceramic production and exchange: A case study from site WKO013A, Koné, New Caledonia. Unpublished PhD thesis, University of California, Berkeley.

Chiu, S. 2007. Detailed analysis of Lapita face motifs: Case studies from Reef-Santa Cruz Lapita sites and New Caledonia Lapita site 13A. In S. Bedford, C. Sand and S.P. Connaughton (eds), Oceanic explorations: Lapita and Western Pacific settlement, pp. 241-264. Terra Australis 26. ANU E Press, Canberra. doi.org/10.22459/TA26.2007.

Chiu, S. and C. Sand 2005. Recording of the Lapita motifs: Proposal for a complete recording method. Archaeology in New Zealand 48(2):133-150.

Clark, G. and A. Anderson 2009. Colonisation and culture change in the Early Prehistory of Fiji. In G. Clark and A. Anderson (eds), The early prehistory of Fiji, pp. 407-437. Terra Australis 31. ANU E Press, Canberra. doi.org/10.22459/TA31.12.2009.16.

Clark, G. and T. Murray 2006. Decay characteristics of the Eastern Lapita design system. Archaeology in Oceania 41(3):107-117. doi.org/10.1002/j.1834-4453.2006.tb00619.x. 
Cochrane, E.E. and C.P. Lipo 2010. Phylogenetic analyses of Lapita decoration do not support branching evolution or regional population structure during colonization of Remote Oceania. Philosophical Transactions of the Royal Society B: Biological Sciences 365(1559):3889-3902. doi.org/10.1098/rstb. 2010.0091.

Delfin, F., S. Myles, Y. Choi, D. Hughes, R. Illek, M. van Oven, B. Pakendorf, M. Kayser and M. Stoneking 2012. Bridging Near and Remote Oceania: MtDNA and NRY variation in the Solomon Islands. Molecular Biology and Evolution 29(2):545-564. doi.org/10.1093/molbev/msr186.

Donovan, L.J. 1973. A study of the decorative system of the Lapita potters in Reefs and Santa Cruz Islands. Unpublished MA thesis, University of Auckland, Auckland.

Friedrich, M.H. 1970. Design structure and social interaction: Archaeological implications of an ethnographic analysis. American Antiquity 35(3):332-343. doi.org/10.2307/278343.

Geraghty, P.A. 1983. The history of the Fijian languages. Oceanic Linguistics Special Publication 19. University of Hawai'i Press, Honolulu.

Green, R.C. 1979. Lapita. In J.D. Jennings (ed.), The prehistory of Polynesia, pp. 27-60. Harvard University Press, Cambridge, Mass. doi.org/10.4159/harvard.9780674181267.c3.

Hardin, M.A. 1984. Models of decoration. In S.E. Van der Leeuw and A.C. Pritchard (eds), The many dimensions of pottery: Ceramics in archaeology and anthropology, pp. 575-607. Universiteit van Amsterdam, Amsterdam.

Hegmon, M. 1994. Boundary-making strategies in Early Pueblo societies: Style and architecture in the Kayenta and Mesa Verde regions. In W.H. Wills and R.D. Leonard (eds), The ancient Southwestern community: Models and methods for the study of prehistoric social organization, pp. 171-190. University of New Mexico Press, Albuquerque.

Hegmon, M. 1995. The social dynamics of pottery style in the early Puebloan Southwest. Crow Canyon Archaeological Center, Tucson.

Hegmon, M. and S. Kulow 2005. Painting as agency, style as structure: Innovations in Mimbres pottery designs from Southwest New Mexico. Journal of Archaeological Method and Theory 12(4):313-334. doi.org/10.1007/s10816-005-8451-5.

Irwin, G., T.H. Worthy, S. Best, S. Hawkins, J. Carpenter and S. Matararaba 2011. Further investigations at the Naigani Lapita site (VL 21/5), Fiji: Excavation, radiocarbon dating and palaeofaunal extinction. Journal of Pacific Archaeology 2(2):66-78.

Jernigan, E.W. 1986. A non-hierarchical approach to ceramic decorative analysis: A Southwestern example. American Antiquity 51(1):3-20. doi.org/10.2307/280390.

Kirch, P.V. 1988. Long-distance exchange and island colonization: The Lapita case. Norwegian Archaeological Review 21(2):103-117. doi.org/10.1080/00293652.1988.9965475.

Kirch, P.V. 1997. The Lapita peoples: Ancestors of the Oceanic world. Blackwell, Cambridge.

LeBlanc, K. 2016a. A structural approach to Lapita design analysis: Investigation of the Eastern Lapita Province. Unpublished PhD thesis, Simon Fraser University, Burnaby, BC.

LeBlanc, K. 2016b. A structural approach to ceramic design analysis: A pilot study of the 'Eastern Lapita Province'. Journal of Archaeological Science: Reports 6:125-135. doi.org/10.1016/j.jasrep.2016.01.032.

Marshall, Y. 1985. Who made the Lapita pots? A case study in gender archaeology. Journal of the Polynesian Society 94(3):205-233.

Mead, S.M. 1975. The decorative system of the Lapita potters of Sigatoka, Fiji. In S.M. Mead, L. Birks, H. Birks and E. Shaw (eds), The Lapita pottery style of Fiji and its associations, pp. 19-43. The Polynesian Society Memoir No 38. Polynesian Society, Wellington. 
Mead, S.M., L. Birks, H. Birks and E. Shaw 1975. The Lapita pottery style of Fiji and its associations. The Polynesian Society Memoir No. 38. Polynesian Society, Wellington.

Nunn, P.D. and F. Petchey 2013. Bayesian re-evaluation of Lapita settlement in Fiji: Radiocarbon analysis of the Lapita occupation at Bourewa and nearby sites on the Rove Peninsula, Viti Levu Island. Journal of Pacific Archaeology 4(2):21-34.

Petchey, F., M. Spriggs, S. Bedford and F. Valentin 2015. The chronology of occupation at Teouma, Vanuatu: Use of a modified chronometric hygiene protocol and Bayesian modeling to evaluate midden remains. Journal of Archaeological Science: Reports 4:95-105. doi.org/10.1016/j.jasrep.2015.08.024.

Plog, S. 1980. Design classification. In S. Plog (ed.), Stylistic variation in prehistoric ceramics, pp. 40-53. Cambridge University Press, New York. doi.org/10.1017/CBO9780511521171.005.

Poulsen, J. 1987. Early Tongan prehistory: The Lapita period on Tongatapu and its relationships. Two volumes. Terra Australis 12. Department of Prehistory, RSPacS, The Australian National University, Canberra.

Sand, C. 1995. Intervention d'urgence sur le site WKO 013 A de Lapita, octobre 1995. Nouvelles découvertes de poteries Lapita à Foué (Koné, Province Nord, Nouvelle-Calédonie). Département Archéologie, Service des Musées et du Patrimoine de Nouvelle-Calédonie, Nouméa.

Sand, C. 2000. The specificities of the 'Southern Lapita Province': The New Caledonian case. Archaeology in Oceania 35(1):20-33. doi.org/10.1002/j.1834-4453.2000.tb00448.x.

Sand, C. 2010. Lapita Calédonien. Archéologie d'un premier peuplement insulaire océanien. Travaux et documents océanistes 2. Société des Océanistes, Paris. doi.org/10.4000/books.sdo.1128.

Sand, C., J. Bolé and A.-J. Ouetcho 2011. A revision of New Caledonia’s ceramic sequence. Journal of Pacific Archaeology 2(1):56-68.

Sharp, N.D. 1988. Style and substance: A reconsideration of the Lapita decorative system. In P.V. Kirch and T.L. Hunt (eds), Archaeology of the Lapita Cultural Complex: A critical review, pp. 61-81. Thomas Burke Memorial Washington State Museum Research Report No. 5. Burke Museum, Seattle.

Shaw, E. 1975. The decorative system of Natunuku, Fiji. In S.M. Mead, L. Birks, H. Birks and E. Shaw (eds), The Lapita pottery style of Fiji and its associations, pp. 44-55. The Polynesian Society, Wellington.

Shepard, A.O. 1956. Ceramics for the archaeologist. Carnegie Institute of Washington, Washington, DC.

Sheppard, P.J. 2011. Lapita colonization across the Near-Remote Oceania boundary. Current Anthropology 52(6):799-840. doi.org/10.1086/662201.

Shipley, G.P., D.A. Taylor, A. Tyagi, G. Tiwari and A.J. Redd 2015. Genetic structure among Fijian Island populations. Journal of Human Genetics 60:69-75. doi.org/10.1038/jhg.2014.105.

Spriggs, M. 1997. The Island Melanesians. Blackwell, Oxford.

Summerhayes, G.R. 2000. Far Western, Western, and Eastern Lapita: A re-evaluation. Asian Perspectives 39(1-2):109-138. doi.org/10.1353/asi.2000.0013.

Washburn, D.K. 1977. A symmetry analysis of Upper Gila Area ceramic design. Papers of the Peabody Museum 68. Harvard University Press, Cambridge.

Washburn, D.K. 1983. Symmetry analysis of ceramic design: Two tests of the method on Neolithic material from Greece and the Aegean. In D. Washburn (ed.), Structure and cognition in art, pp. 138164. Cambridge University Press, New York.

Washburn, D.K. and D.W. Crowe (eds) 1988. Symmetries of culture: Theory and practice of plane pattern analysis. University of Washington Press, Seattle. 


\section{Appendix 14.1}

Table 14A.1. Post-hoc comparisons of density attribute distribution between Lapita samples from the Eastern, Western and Southern Provinces.

\begin{tabular}{|c|c|c|c|c|c|c|}
\hline $\begin{array}{l}\text { Dentate density } \\
\alpha=0.037\end{array}$ & Early Tonga & Late Tonga & West Fiji & East Fiji & New Caledonia & Vanuatu \\
\hline $\begin{array}{l}\text { Significantly } \\
\text { different from: }\end{array}$ & $\begin{array}{l}\text { West Fiji } \\
(p=0.0001), \\
\text { Late Tonga } \\
(p=0.0040), \\
\text { Vanuatu } \\
(p=0.0001)\end{array}$ & $\begin{array}{l}\text { Early Tonga } \\
(p=0.0040), \\
\text { West Fiji } \\
(p=0.0001), \\
\text { New Caledonia } \\
(p=0.0001), \\
\text { Vanuatu } \\
(p=0.0001)\end{array}$ & $\begin{array}{l}\text { Early Tonga } \\
(p=0.0001), \\
\text { New Caledonia } \\
(p=0.0078), \\
\text { Late Tonga } \\
(p=0.0001), \\
\text { East Fiji } \\
(p=0.0001)\end{array}$ & $\begin{array}{l}\text { New Caledonia } \\
(p=0.0012), \\
\text { West Fiji } \\
(p=0.0001), \\
\text { Vanuatu } \\
(p=0.0001)\end{array}$ & $\begin{array}{l}\text { East Fiji } \\
(p=0.0012), \\
\text { West Fiji } \\
(p=0.0078), \\
\text { Late Tonga } \\
(p=0.0001), \\
\text { Vanuatu } \\
(p=0.0001)\end{array}$ & $\begin{array}{l}\text { Early Tonga } \\
(p=0.0001), \\
\text { Late Tonga } \\
(p=0.0001), \\
\text { East Fiji } \\
(p=0.0001), \\
\text { New Caledonia } \\
(p=0.0001)\end{array}$ \\
\hline $\begin{array}{l}\text { Not significantly } \\
\text { different from: }\end{array}$ & $\begin{array}{l}\text { New Caledonia } \\
(p=0.0903), \\
\text { East Fiji } \\
(p=0.1129)\end{array}$ & $\begin{array}{l}\text { East Fiji } \\
(p=0.1858)\end{array}$ & $\begin{array}{l}\text { Vanuatu } \\
(p=0.0422)\end{array}$ & $\begin{array}{l}\text { Early Tonga } \\
(p=0.1129), \\
\text { Late Tonga } \\
(p=0.1858)\end{array}$ & $\begin{array}{l}\text { Early Tonga } \\
(p=0.0903)\end{array}$ & $\begin{array}{l}\text { West Fiji } \\
(p=0.0422)\end{array}$ \\
\hline
\end{tabular}

Chart indicates which groups differ significantly by indication of statistical $p$ values. Statistical significance is determined at an $\alpha$ level calculated using the Benjamini-Hochberg method.

Source: Table prepared by Kathleen LeBlanc.

Table 14A.2. Post-hoc comparisons of attribute distribution between Lapita samples in the Eastern, Western and Southern Provinces.

\begin{tabular}{|c|c|c|c|c|c|c|}
\hline $\begin{array}{l}\text { Leica MZ6 } \\
\text { attributes }\end{array}$ & Early Tonga & Late Tonga & West Fiji & East Fiji & New Caledonia & Vanuatu \\
\hline \multicolumn{7}{|c|}{ Dentate length $\alpha=0.037$} \\
\hline $\begin{array}{l}\text { Significantly } \\
\text { different from: }\end{array}$ & \begin{tabular}{|l|} 
Late Tonga \\
$(p=0.0064)$, \\
West Fiji \\
$(p=0.0047)$, \\
East Fiji \\
$(p=0.0001)$, \\
New Caledonia \\
$(p=0.0109)$, \\
Vanuatu \\
$(p=0.0058)$ \\
\end{tabular} & \begin{tabular}{|l|} 
Early Tonga \\
$(p=0.0064)$, \\
West Fiji \\
$(p=0.0001)$, \\
New Caledonia \\
$(p=0.0001)$, \\
Vanuatu \\
$(p=0.0001)$
\end{tabular} & $\begin{array}{l}\text { Early Tonga } \\
(p=0.0047), \\
\text { Late Tonga } \\
(p=0.0001), \\
\text { East Fiji } \\
(p=0.0001)\end{array}$ & $\begin{array}{l}\text { Early Tonga } \\
(p=0.0001), \\
\text { West Fiji } \\
(p=0.0001), \\
\text { New Caledonia } \\
(p=0.0001), \\
\text { Vanuatu } \\
(p=0.0001)\end{array}$ & $\begin{array}{l}\text { Early Tonga } \\
(p=0.0109), \\
\text { Late Tonga } \\
(p=0.0001), \\
\text { East Fiji } \\
(p=0.0001)\end{array}$ & $\begin{array}{l}\text { Early Tonga } \\
(p=0.0058), \\
\text { Late Tonga } \\
(p=0.0001), \\
\text { East Fiji } \\
(p=0.0001)\end{array}$ \\
\hline $\begin{array}{l}\text { Not significantly } \\
\text { different from: }\end{array}$ & - & $\begin{array}{l}\text { East Fiji } \\
(p=0.1801)\end{array}$ & $\begin{array}{l}\text { New Caledonia } \\
(p=0.6602), \\
\text { Vanuatu } \\
(p=0.9033)\end{array}$ & $\begin{array}{l}\text { Late Tonga } \\
(p=0.1801)\end{array}$ & $\begin{array}{l}\text { West Fiji } \\
(p=0.6602), \\
\text { Vanuatu } \\
(p=0.5937) \\
\end{array}$ & $\begin{array}{l}\text { West Fiji } \\
(p=0.9033), \\
\text { New Caledonia } \\
(p=0.5937)\end{array}$ \\
\hline \multicolumn{7}{|c|}{ Dentate width $\alpha=0.027$} \\
\hline $\begin{array}{l}\text { Significantly } \\
\text { different from: }\end{array}$ & $\begin{array}{l}\text { Late Tonga } \\
(p=0.0003), \\
\text { East Fiji } \\
(p=0.0081)\end{array}$ & \begin{tabular}{|l} 
Early Tonga \\
$(p=0.0003)$, \\
West Fiji \\
$(p=0.0001)$, \\
New Caledonia \\
$(p=0.0002)$, \\
Vanuatu \\
$(p=0.0008)$ \\
\end{tabular} & $\begin{array}{l}\text { Late Tonga } \\
(p=0.0001), \\
\text { East Fiji } \\
(p=0.0007)\end{array}$ & $\begin{array}{l}\text { Early Tonga } \\
(p=0.0081), \\
\text { West Fiji } \\
(p=0.0007), \\
\text { New Caledonia } \\
(p=0.0037), \\
\text { Vanuatu } \\
(p=0.0080) \\
\end{array}$ & $\begin{array}{l}\text { Late Tonga } \\
(p=0.0002), \\
\text { East Fiji } \\
(p=0.0037)\end{array}$ & $\begin{array}{l}\text { Late Tonga } \\
(p=0.0008), \\
\text { East Fiji } \\
(p=0.0080)\end{array}$ \\
\hline
\end{tabular}




\begin{tabular}{|c|c|c|c|c|c|c|}
\hline $\begin{array}{l}\text { Leica MZ6 } \\
\text { attributes }\end{array}$ & Early Tonga & Late Tonga & West Fiji & East Fiji & New Caledonia & Vanuatu \\
\hline $\begin{array}{l}\text { Not significantly } \\
\text { different from: }\end{array}$ & $\begin{array}{l}\text { West Fiji } \\
(p=0.2693), \\
\text { New Caledonia } \\
(p=0.7292), \\
\text { Vanuatu } \\
(p=0.6399)\end{array}$ & $\begin{array}{l}\text { East Fiji } \\
(p=0.2751)\end{array}$ & $\begin{array}{l}\text { Early Tonga } \\
(p=0.2693), \\
\text { New Caledonia } \\
(p=0.4189), \\
\text { Vanuatu } \\
(p=0.5235)\end{array}$ & $\begin{array}{l}\text { Late Tonga } \\
(p=0.2751)\end{array}$ & $\begin{array}{l}\text { Early Tonga } \\
(p=0.7292), \\
\text { West Fiji } \\
(p=0.4189), \\
\text { Vanuatu } \\
(p=0.8658)\end{array}$ & $\begin{array}{l}\text { Early Tonga } \\
(p=0.6399), \\
\text { West Fiji } \\
(p=0.5235), \\
\text { Vanuatu } \\
(p=0.8658)\end{array}$ \\
\hline \multicolumn{7}{|c|}{ Dentate spacing $1 \alpha=0.01$} \\
\hline $\begin{array}{l}\text { Significantly } \\
\text { different from: }\end{array}$ & - & - & $\begin{array}{l}\text { East Fiji } \\
(p=0.0004)\end{array}$ & $\begin{array}{l}\text { West Fiji } \\
(p=0.0004), \\
\text { New Caledonia } \\
(p=0.0015), \\
\text { Vanuatu } \\
(p=0.0002) \\
\end{array}$ & $\begin{array}{l}\text { East Fiji } \\
(p=0.0015)\end{array}$ & $\begin{array}{l}\text { East Fiji } \\
(p=0.0002)\end{array}$ \\
\hline $\begin{array}{l}\text { Not significantly } \\
\text { different from: }\end{array}$ & $\begin{array}{l}\text { Late Tonga } \\
(p=0.3769), \\
\text { West Fiji } \\
(p=0.1084), \\
\text { East Fiji } \\
(p=0.0207), \\
\text { New Caledonia } \\
(p=0.3271), \\
\text { Vanuatu } \\
(p=0.0562) \\
\end{array}$ & $\begin{array}{l}\text { Early Tonga } \\
(p=0.3769), \\
\text { West Fiji } \\
(p=0.0262), \\
\text { East Fiji } \\
(p=0.1524), \\
\text { New Caledonia } \\
(p=0.0776), \\
\text { Vanuatu } \\
(p=0.0159)\end{array}$ & $\begin{array}{l}\text { Early Tonga } \\
(p=0.1084), \\
\text { Late Tonga } \\
(p=0.0262), \\
\text { New Caledonia } \\
(p=0.4789), \\
\text { Vanuatu } \\
(p=0.6474)\end{array}$ & $\begin{array}{l}\text { Early Tonga } \\
(p=0.0207), \\
\text { Late Tonga } \\
(p=0.1524)\end{array}$ & $\begin{array}{l}\text { Early Tonga } \\
(p=0.3271), \\
\text { Late Tonga } \\
(p=0.0776), \\
\text { West Fiji } \\
(p=0.4789), \\
\text { Vanuatu } \\
(p=0.2693)\end{array}$ & $\begin{array}{l}\text { Early Tonga } \\
(p=0.0562), \\
\text { Late Tonga } \\
(p=0.0159), \\
\text { West Fiji } \\
(p=0.6474), \\
\text { New Caledonia } \\
(p=0.2693)\end{array}$ \\
\hline 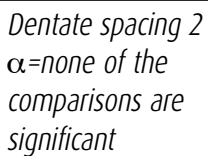 & - & - & - & - & - & - \\
\hline
\end{tabular}

Chart indicates which attributes do and do not differ significantly between groups by indication of statistical $p$ values. Statistical significance is determined at different $\alpha$ values depending on the attribute analysed using the Benjamini-Hochberg method. Adjusted significance values are noted next to the attribute name in the chart.

Source: Table prepared by Kathleen LeBlanc.

Table 14A.3. Post-hoc comparisons of attribute distribution between Lapita samples from the Eastern, Western and Southern Provinces.

\begin{tabular}{|c|c|c|c|c|c|c|}
\hline LEXT attributes & Early Tonga & Late Tonga & West Fiji & East Fiji & New Caledonia & Vanuatu \\
\hline \multicolumn{7}{|c|}{ Dentate length $\alpha=0.027$} \\
\hline $\begin{array}{l}\text { Significantly } \\
\text { different from: }\end{array}$ & $\begin{array}{l}\text { West Fiji } \\
(p=0.0051), \\
\text { Vanuatu } \\
(p=0.0063)\end{array}$ & $\begin{array}{l}\text { West Fiji } \\
(p=0.0001), \\
\text { New Caledonia } \\
(p=0.0013), \\
\text { Vanuatu } \\
(p=0.0002)\end{array}$ & $\begin{array}{l}\text { Early Tonga } \\
(p=0.0051), \\
\text { Late Tonga } \\
(p=0.0001), \\
\text { East Fiji } \\
(p=0.0001)\end{array}$ & $\begin{array}{l}\text { West Fiji } \\
(p=0.0001), \\
\text { New Caledonia } \\
(p=0.0025), \\
\text { Vanuatu } \\
(p=0.0002)\end{array}$ & $\begin{array}{l}\text { Late Tonga } \\
(p=0.0013), \\
\text { East Fiji } \\
(p=0.0025)\end{array}$ & $\begin{array}{l}\text { Early Tonga } \\
(p=0.0063), \\
\text { Late Tonga } \\
(p=0.0002), \\
\text { East Fiji } \\
(p=0.0002)\end{array}$ \\
\hline $\begin{array}{l}\text { Not significantly } \\
\text { different from: }\end{array}$ & $\begin{array}{l}\text { Late Tonga } \\
(p=0.0721), \\
\text { East Fiji } \\
(p=0.1210), \\
\text { New Caledonia } \\
(p=0.0063)\end{array}$ & $\begin{array}{l}\text { Early Tonga } \\
(p=0.0721), \\
\text { East Fiji } \\
(p=0.7766)\end{array}$ & $\begin{array}{l}\text { New Caledonia } \\
(p=0.1680), \\
\text { Vanuatu } \\
(p=0.8339)\end{array}$ & $\begin{array}{l}\text { Early Tonga } \\
(p=0.1210), \\
\text { Late Tonga } \\
(p=0.7766)\end{array}$ & $\begin{array}{l}\text { Early Tonga } \\
(p=0.0063), \\
\text { West Fiji } \\
(p=0.1680), \\
\text { Vanuatu } \\
(p=0.1457)\end{array}$ & $\begin{array}{l}\text { West Fiji } \\
(p=0.8339), \\
\text { New Caledonia } \\
(p=0.1457)\end{array}$ \\
\hline
\end{tabular}




\begin{tabular}{|c|c|c|c|c|c|c|}
\hline LEXT attributes & Early Tonga & Late Tonga & West Fiji & East Fiji & New Caledonia & Vanuatu \\
\hline \multicolumn{7}{|c|}{ Dentate area $\alpha=0.017$} \\
\hline $\begin{array}{l}\text { Significantly } \\
\text { different from: }\end{array}$ & $\begin{array}{l}\text { West Fiji } \\
(p=0.0051)\end{array}$ & $\begin{array}{l}\text { West Fiji } \\
(p=0.0089)\end{array}$ & $\begin{array}{l}\text { Early Tonga } \\
(p=0.0051), \\
\text { Late Tonga } \\
(p=0.0089), \\
\text { East Fiji } \\
(p=0.0001), \\
\text { New Caledonia } \\
(p=0.0164), \\
\text { Vanuatu } \\
(p=0.0001) \\
\end{array}$ & $\begin{array}{l}\text { West Fiji } \\
(p=0.0001), \\
\text { New Caledonia } \\
(p=0.0103), \\
\text { Vanuatu } \\
(p=0.0001)\end{array}$ & $\begin{array}{l}\text { West Fiji } \\
(p=0.0164), \\
\text { East Fiji } \\
(p=0.0103), \\
\text { Vanuatu } \\
(p=0.0001)\end{array}$ & $\begin{array}{l}\text { West Fiji } \\
(p=0.0001), \\
\text { East Fiji } \\
(p=0.0001), \\
\text { New Caledonia } \\
(p=0.0001)\end{array}$ \\
\hline $\begin{array}{l}\text { Not significantly } \\
\text { different from: }\end{array}$ & $\begin{array}{l}\text { Late Tonga } \\
(p=0.9970), \\
\text { East Fiji } \\
(p=0.0991), \\
\text { New Caledonia } \\
(p=0.3008), \\
\text { Vanuatu } \\
(p=0.0701)\end{array}$ & $\begin{array}{l}\text { Early Tonga } \\
(p=0.9970), \\
\text { East Fiji } \\
(p=0.0988), \\
\text { New Caledonia } \\
(p=0.3149), \\
\text { Vanuatu } \\
(p=0.0981)\end{array}$ & - & $\begin{array}{l}\text { Early Tonga } \\
(p=0.0991), \\
\text { Late Tonga } \\
(p=0.0988)\end{array}$ & $\begin{array}{l}\text { Early Tonga } \\
(p=0.3008), \\
\text { Late Tonga } \\
(p=0.3149)\end{array}$ & $\begin{array}{l}\text { Early Tonga } \\
(p=0.0701), \\
\text { Late Tonga } \\
(p=0.0981)\end{array}$ \\
\hline \multicolumn{7}{|c|}{ Surface area $\alpha=0.033$} \\
\hline $\begin{array}{l}\text { Significantly } \\
\text { different from: }\end{array}$ & $\begin{array}{l}\text { West Fiji } \\
(p=0.0029), \\
\text { Vanuatu } \\
(p=0.0001)\end{array}$ & $\begin{array}{l}\text { West Fiji } \\
(p=0.0002), \\
\text { Vanuatu } \\
(p=0.0001)\end{array}$ & $\begin{array}{l}\text { Early Tonga } \\
(p=0.0029), \\
\text { Late Tonga } \\
(p=0.0002), \\
\text { East Fiji } \\
(p=0.0001), \\
\text { New Caledonia } \\
(p=0.0164), \\
\text { Vanuatu } \\
(p=0.0001)\end{array}$ & $\begin{array}{l}\text { West Fiji } \\
(p=0.0001), \\
\text { New Caledonia } \\
(p=0.0103), \\
\text { Vanuatu } \\
(p=0.0001)\end{array}$ & $\begin{array}{l}\text { West Fiji } \\
(p=0.0164), \\
\text { East Fiji } \\
(p=0.0103), \\
\text { Vanuatu } \\
(p=0.0001)\end{array}$ & $\begin{array}{l}\text { Early Tonga } \\
(p=0.0001), \\
\text { Late Tonga } \\
(p=0.0001), \\
\text { West Fiji } \\
(p=0.0001), \\
\text { East Fiji } \\
(p=0.0001), \\
\text { New Caledonia } \\
(p=0.0001)\end{array}$ \\
\hline $\begin{array}{l}\text { Not significantly } \\
\text { different from: }\end{array}$ & $\begin{array}{l}\text { Late Tonga } \\
(p=0.3642), \\
\text { East Fiji } \\
(p=0.0487), \\
\text { New Caledonia } \\
(p=0.5245) \\
\end{array}$ & $\begin{array}{l}\text { Early Tonga } \\
(p=0.3642), \\
\text { East Fiji } \\
(p=0.2754), \\
\text { New Caledonia } \\
(p=0.1256)\end{array}$ & - & $\begin{array}{l}\text { Early Tonga } \\
(p=0.0487), \\
\text { Late Tonga } \\
(p=0.2754)\end{array}$ & $\begin{array}{l}\text { Early Tonga } \\
(p=0.5245), \\
\text { Late Tonga } \\
(p=0.1256)\end{array}$ & - \\
\hline $\begin{array}{l}\text { Dentate } \\
\text { depth } \alpha=n o \\
\text { comparisons } \\
\text { are statistically } \\
\text { significant }\end{array}$ & - & - & - & - & - & - \\
\hline $\begin{array}{l}\text { Dentate } \\
\text { volume } \alpha=n o \\
\text { comparisons } \\
\text { are statistically } \\
\text { significant }\end{array}$ & - & - & - & - & - & - \\
\hline
\end{tabular}

Chart indicates which attributes do and do not differ significantly between groups by indication of statistical $p$ values.

Statistical significance is determined at different $\alpha$ values depending on the attribute analysed using the Benjamini-Hochberg method. Adjusted significance values are noted next to the attribute name in the chart.

Source: Table prepared by Kathleen LeBlanc. 
Table 14A.4. Post-hoc comparisons of categorical attributes between Lapita samples from the Eastern, Western and Southern Provinces.

\begin{tabular}{|c|c|c|c|c|c|c|}
\hline $\begin{array}{l}\text { Categorical } \\
\text { attributes }\end{array}$ & Early Tonga & Late Tonga & West Fiji & East Fiji & New Caledonia & Vanuatu \\
\hline \multicolumn{7}{|c|}{ Symmetry $\alpha=0.023$} \\
\hline $\begin{array}{l}\text { Significantly } \\
\text { different from: }\end{array}$ & $\begin{array}{l}\text { New Caledonia } \\
(p=0.001)\end{array}$ & $\begin{array}{l}\text { New Caledonia } \\
(p=0.000) \\
\text { Vanuatu } \\
(p=0.001)\end{array}$ & $\begin{array}{l}\text { New Caledonia } \\
(p=0.001)\end{array}$ & $\begin{array}{l}\text { New Caledonia } \\
(p=0.000), \\
\text { Vanuatu } \\
(p=0.005)\end{array}$ & $\begin{array}{l}\text { Early Tonga } \\
(p=0.001), \\
\text { Late Tonga } \\
(p=0.000), \\
\text { West Fiji } \\
(p=0.001), \text { East } \\
\text { Fiji }(p=0.000), \\
\text { Vanuatu } \\
(p=0.005) \\
\end{array}$ & $\begin{array}{l}\text { Late Tonga } \\
(p=0.001), \text { East } \\
\text { Fiji }(p=0.005), \\
\text { New Caledonia } \\
(p=0.005)\end{array}$ \\
\hline $\begin{array}{l}\text { Not significantly } \\
\text { different from: }\end{array}$ & $\begin{array}{l}\text { Late Tonga } \\
(p=0.070), \\
\text { West Fiji } \\
(p=0.748), \text { East } \\
\text { Fiji }(p=0.142) \text {, } \\
\text { Vanuatu } \\
(p=0.037) \\
\end{array}$ & $\begin{array}{l}\text { Early Tonga } \\
(p=0.070), \\
\text { West Fiji } \\
(p=0.140), \text { East } \\
\text { Fiji }(p=0.081)\end{array}$ & \begin{tabular}{|l} 
Early Tonga \\
$(p=0.748)$, \\
Late Tonga \\
$(p=0.140)$, East \\
Fiji $(p=0.676)$, \\
Vanuatu \\
$(p=0.122)$ \\
\end{tabular} & $\begin{array}{l}\text { Early Tonga } \\
(p=0.142), \\
\text { Late Tonga } \\
(p=0.081), \\
\text { West Fiji } \\
(p=0.676)\end{array}$ & - & $\begin{array}{l}\text { Early Tonga } \\
(p=0.037), \\
\text { West Fiji } \\
(p=0.122)\end{array}$ \\
\hline \multicolumn{7}{|c|}{ Zone direction $\alpha=0.017$} \\
\hline $\begin{array}{l}\text { Significantly } \\
\text { different from: }\end{array}$ & $\begin{array}{l}\text { Vanuatu } \\
(p=0.000)\end{array}$ & $\begin{array}{l}\text { Vanuatu } \\
(p=0.000)\end{array}$ & $\begin{array}{l}\text { Vanuatu } \\
(p=0.000),\end{array}$ & $\begin{array}{l}\text { Vanuatu } \\
(p=0.000)\end{array}$ & $\begin{array}{l}\text { Vanuatu } \\
(p=0.000)\end{array}$ & $\begin{array}{l}\text { Early Tonga } \\
(p=0.000), \\
\text { Late Tonga } \\
(p=0.000), \\
\text { West Fiji } \\
(p=0.000), \text { East } \\
\text { Fiji }(p=0.000), \\
\text { New Caledonia } \\
(p=0.000)\end{array}$ \\
\hline $\begin{array}{l}\text { Not significantly } \\
\text { different from: }\end{array}$ & \begin{tabular}{|l|} 
Late Tonga \\
$(p=0.132)$, \\
West Fiji \\
$(p=0.438)$, East \\
Fiji $(p=0.722)$, \\
New Caledonia \\
$(p=0.287)$ \\
\end{tabular} & \begin{tabular}{|l} 
Early Tonga \\
$(p=0.132)$, \\
West Fiji \\
$(p=1.000)$, East \\
Fiji $(p=0.196)$, \\
New Caledonia \\
$(p=0.039)$ \\
\end{tabular} & $\begin{array}{l}\text { Early Tonga } \\
(p=0.438), \\
\text { Late Tonga } \\
(p=1.000), \text { East } \\
\text { Fiji }(p=0.589), \\
\text { New Caledonia } \\
(p=0.082) \\
\end{array}$ & \begin{tabular}{|l|} 
Early Tonga \\
$(p=0.722)$, \\
Late Tonga \\
$(p=0.196)$, West \\
Fiji $(p=0.589)$, \\
New Caledonia \\
$(p=0.913)$
\end{tabular} & $\begin{array}{l}\text { Early Tonga } \\
(p=0.287), \\
\text { Late Tonga } \\
(p=0.039), \\
\text { West Fiji } \\
(p=0.082), \text { East } \\
\text { Fiji }(p=0.913)\end{array}$ & - \\
\hline \multicolumn{7}{|c|}{ Motif infilling $\alpha=0.03$} \\
\hline $\begin{array}{l}\text { Significantly } \\
\text { different from: }\end{array}$ & $\begin{array}{l}\text { Late Tonga } \\
(p=0.021), \text { West } \\
\text { Fiji }(p=0.006), \\
\text { Vanuatu } \\
(p=0.000)\end{array}$ & \begin{tabular}{|l} 
Early Tonga \\
$(p=0.021)$, West \\
Fiji $(p=0.000)$, \\
New Caledonia \\
$(p=0.000)$, \\
Vanuatu \\
$(p=0.000)$ \\
\end{tabular} & $\begin{array}{l}\text { Early Tonga } \\
(p=0.006), \\
\text { Late Tonga } \\
(p=0.000), \text { East } \\
\text { Fiji }(p=0.000)\end{array}$ & $\begin{array}{l}\text { West Fiji } \\
(p=0.000), \\
\text { New Caledonia } \\
(p=0.000), \\
\text { Vanuatu } \\
(p=0.000)\end{array}$ & $\begin{array}{l}\text { Late Tonga } \\
(p=0.000) \text {, East } \\
\text { Fiji }(p=0.000)\end{array}$ & $\begin{array}{l}\text { Early Tonga } \\
(p=0.000), \\
\text { Late Tonga } \\
(p=0.000), \text { East } \\
\text { Fiji }(p=0.000)\end{array}$ \\
\hline $\begin{array}{l}\text { Not significantly } \\
\text { different from: }\end{array}$ & \begin{tabular}{|l|} 
East Fiji \\
$(p=0.193)$, \\
New Caledonia \\
$(p=0.075)$
\end{tabular} & $\begin{array}{l}\text { East Fiji } \\
(p=0.617)\end{array}$ & $\begin{array}{l}\text { New Caledonia } \\
(p=0.071), \\
\text { Vanuatu } \\
(p=0.247)\end{array}$ & $\begin{array}{l}\text { Early Tonga } \\
(\rho=0.193), \\
\text { Late Tonga } \\
(\rho=0.617)\end{array}$ & \begin{tabular}{|l|} 
Early Tonga \\
$(p=0.075)$, West \\
Fiji $(p=0.071)$, \\
Vanuatu \\
$(p=0.038)$
\end{tabular} & $\begin{array}{l}\text { West Fiji } \\
(p=0.247), \\
\text { New Caledonia } \\
(p=0.038)\end{array}$ \\
\hline
\end{tabular}

The $\alpha$ value was determined using the Benjamini-Hochberg method and is indicated after the attribute name.

Source: Table prepared by Kathleen LeBlanc. 
Table 14A.5. Post-hoc comparisons resulting from individual Fischer's Exact tests between sample groups from the Eastern, Western and Southern Lapita Provinces.

\begin{tabular}{|c|c|c|c|c|c|c|}
\hline Attributes & Early Tonga & Late Tonga & West Fiji & East Fiji & New Caledonia & Vanuatu \\
\hline \multicolumn{7}{|c|}{ Element frequency $\alpha=0.037$} \\
\hline $\begin{array}{l}\text { Significantly } \\
\text { different from: }\end{array}$ & $\begin{array}{l}\text { West Fiji } \\
(p=0.007), \\
\text { New Caledonia } \\
(p=0.001) \\
\text { Vanuatu } \\
(p=0.003)\end{array}$ & $\begin{array}{l}\text { West Fiji } \\
(p=0.012), \\
\text { New Caledonia } \\
(p=0.002), \\
\text { Vanuatu } \\
(p=0.000)\end{array}$ & $\begin{array}{l}\text { Early Tonga } \\
(p=0.007), \\
\text { Late Tonga } \\
(p=0.012), \text { East } \\
\text { Fiji }(p=0.011), \\
\text { Vanuatu } \\
(p=0.035)\end{array}$ & $\begin{array}{l}\text { West Fiji } \\
(p=0.011), \\
\text { New Caledonia } \\
(p=0.020) \\
\text { Vanuatu } \\
(p=0.001)\end{array}$ & $\begin{array}{l}\text { Early Tonga } \\
(p=0.001), \\
\text { Late Tonga } \\
(p=0.002), \text { East } \\
\text { Fiji }(p=0.020), \\
\text { Vanuatu } \\
(p=0.000)\end{array}$ & $\begin{array}{l}\text { Early Tonga } \\
(p=0.003), \\
\text { Late Tonga } \\
(p=0.000), \\
\text { West Fiji } \\
(p=0.035), \text { East } \\
\text { Fiji }(p=0.001), \\
\text { New Caledonia } \\
(p=0.000)\end{array}$ \\
\hline $\begin{array}{l}\text { Not significantly } \\
\text { different from: }\end{array}$ & $\begin{array}{l}\text { Late Tonga } \\
(p=0.816) \text {, East } \\
\text { Fiji }(p=0.351)\end{array}$ & $\begin{array}{l}\text { Early Tonga } \\
(p=0.816) \text {, East } \\
\text { Fiji }(p=0.379)\end{array}$ & $\begin{array}{l}\text { New Caledonia } \\
(p=0.061)\end{array}$ & $\begin{array}{l}\text { Early Tonga } \\
(p=0.351), \\
\text { Late Tonga } \\
(p=0.379)\end{array}$ & $\begin{array}{l}\text { West Fiji } \\
(p=0.061)\end{array}$ & - \\
\hline \multicolumn{7}{|c|}{ Motif frequency $\alpha=0.037$} \\
\hline $\begin{array}{l}\text { Significantly } \\
\text { different from: }\end{array}$ & $\begin{array}{l}\text { West Fiji } \\
(p=0.010), \text { East } \\
\text { Fiji }(p=0.008), \\
\text { New Caledonia } \\
(p=0.002), \\
\text { Vanuatu } \\
(p=0.000)\end{array}$ & $\begin{array}{l}\text { Vanuatu } \\
(p=0.001)\end{array}$ & $\begin{array}{l}\text { Early Tonga } \\
(p=0.010), \text { East } \\
\text { Fiji }(p=0.001) \text {, } \\
\text { New Caledonia } \\
(p=0.001), \\
\text { Vanuatu } \\
(p=0.015)\end{array}$ & $\begin{array}{l}\text { Early Tonga } \\
(p=0.008), \text { West } \\
\text { Fiji }(p=0.001), \\
\text { New Caledonia } \\
(p=0.001), \\
\text { Vanuatu } \\
(p=0.000)\end{array}$ & $\begin{array}{l}\text { Early Tonga } \\
(p=0.002), \\
\text { West Fiji } \\
(p=0.001), \text { East } \\
\text { Fiji }(p=0.001), \\
\text { Vanuatu } \\
(p=0.001)\end{array}$ & $\begin{array}{l}\text { Early Tonga } \\
(p=0.000), \\
\text { Late Tonga } \\
(p=0.001), \\
\text { West Fiji } \\
(p=0.015), \text { East } \\
\text { Fiji }(p=0.000), \\
\text { New Caledonia } \\
(p=0.001)\end{array}$ \\
\hline $\begin{array}{l}\text { Not significantly } \\
\text { different from: }\end{array}$ & $\begin{array}{l}\text { Late Tonga } \\
(p=0.747)\end{array}$ & $\begin{array}{l}\text { Early Tonga } \\
(p=0.747), \text { East } \\
\text { Fiji }(p=0.406), \\
\text { West Fiji } \\
(p=0.136), \\
\text { New Caledonia } \\
(p=0.583)\end{array}$ & $\begin{array}{l}\text { Late Tonga } \\
(p=0.136)\end{array}$ & $\begin{array}{l}\text { Late Tonga } \\
(p=0.406)\end{array}$ & $\begin{array}{l}\text { Late Tonga } \\
(p=0.583)\end{array}$ & - \\
\hline \multicolumn{7}{|c|}{ Process frequency $\alpha=0.01$} \\
\hline $\begin{array}{l}\text { Significantly } \\
\text { different from: }\end{array}$ & $\begin{array}{l}\text { New Caledonia } \\
(p=0.001)\end{array}$ & - & - & $\begin{array}{l}\text { New Caledonia } \\
(p=0.000)\end{array}$ & $\begin{array}{l}\text { Early Tonga } \\
(p=0.001), \text { East } \\
\text { Fiji }(p=0.000) \text {, } \\
\text { Vanuatu } \\
(p=0.000)\end{array}$ & $\begin{array}{l}\text { New Caledonia } \\
(p=0.000)\end{array}$ \\
\hline $\begin{array}{l}\text { Not significantly } \\
\text { different from: }\end{array}$ & \begin{tabular}{|l} 
Late Tonga \\
$(p=0.561)$, \\
West Fiji \\
$(p=0.130)$, East \\
Fiji $(p=0.519)$, \\
Vanuatu \\
$(p=0.030)$
\end{tabular} & $\begin{array}{l}\text { Early Tonga } \\
(p=0.561), \text { East } \\
\text { Fiji }(p=0.149), \\
\text { West Fiji } \\
(p=0.759), \\
\text { New Caledonia } \\
(p=0.028), \\
\text { Vanuatu } \\
(p=0.030)\end{array}$ & $\begin{array}{l}\text { Early Tonga } \\
(p=0.130), \\
\text { Late Tonga } \\
(p=0.759), \text { East } \\
\text { Fiji }(p=0.033), \\
\text { New Caledonia } \\
(p=0.040), \\
\text { Vanuatu } \\
(p=0.048)\end{array}$ & $\begin{array}{l}\text { Early Tonga } \\
(p=0.519), \\
\text { Late Tonga } \\
(p=0.149), \text { West } \\
\text { Fiji }(p=0.033), \\
\text { Vanuatu } \\
(p=0.027)\end{array}$ & $\begin{array}{l}\text { Late Tonga } \\
(p=0.028), \\
\text { West Fiji } \\
(p=0.040)\end{array}$ & $\begin{array}{l}\text { Early Tonga } \\
(p=0.030), \\
\text { Late Tonga } \\
(p=0.030), \\
\text { West Fiji } \\
(p=0.048), \text { East } \\
\text { Fiji }(p-0.027)\end{array}$ \\
\hline
\end{tabular}

The $\alpha$ value was determined using the Benjamini-Hochberg method and is provided after the attribute name. Source: Table prepared by Kathleen LeBlanc. 
302

Debating Lapita

Table 14A.6. Frequency counts and percentages for element type in each sample group.

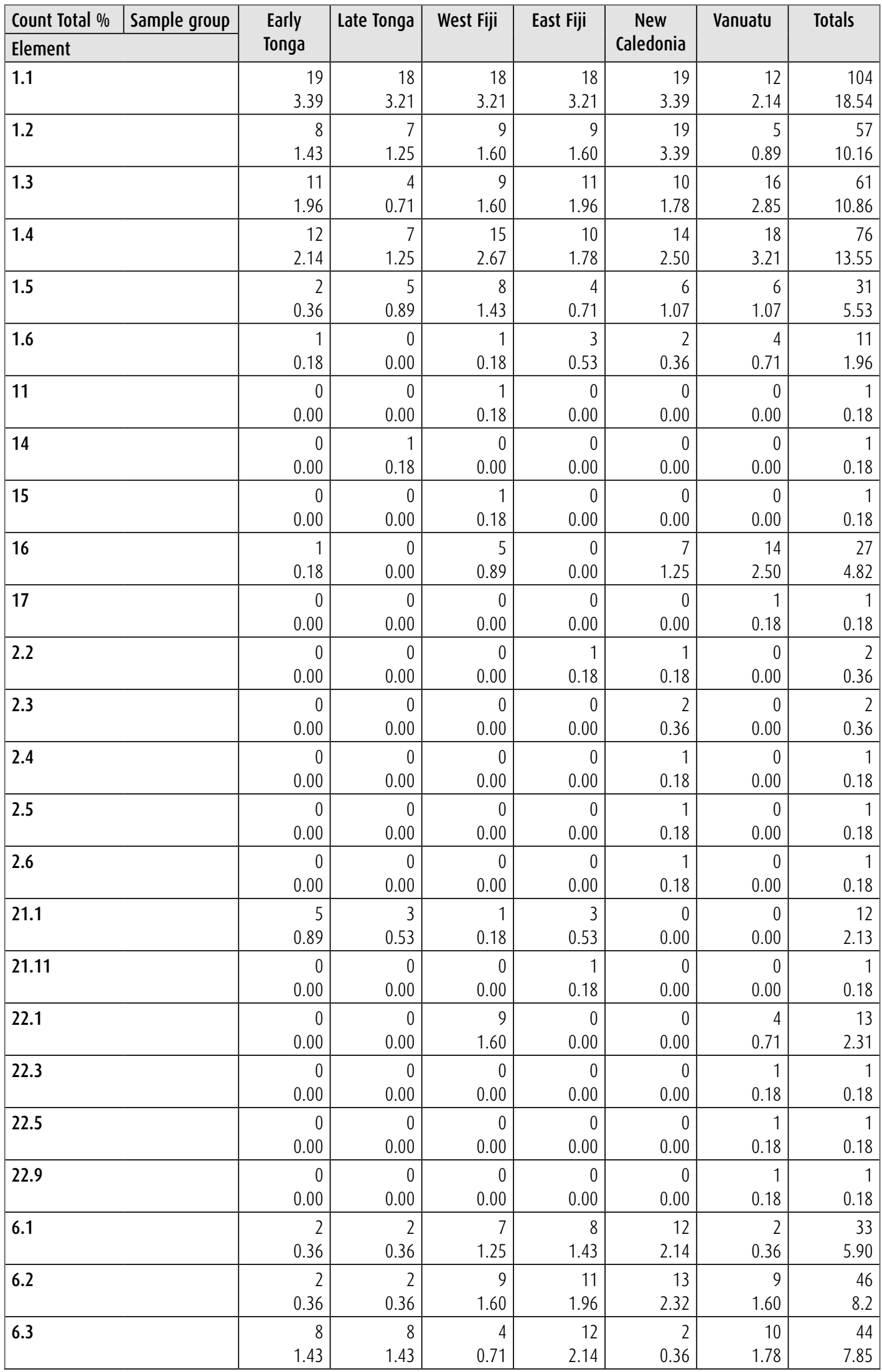




\begin{tabular}{|c|c|c|c|c|c|c|c|c|}
\hline Count Total \% & Sample group & \multirow{2}{*}{$\begin{array}{l}\text { Early } \\
\text { Tonga }\end{array}$} & \multirow[t]{2}{*}{ Late Tonga } & \multirow[t]{2}{*}{ West Fiji } & \multirow[t]{2}{*}{ East Fiji } & \multirow{2}{*}{$\begin{array}{c}\text { New } \\
\text { Caledonia }\end{array}$} & \multirow[t]{2}{*}{ Vanuatu } & \multirow[t]{2}{*}{ Totals } \\
\hline Element & & & & & & & & \\
\hline 6.4 & & $\begin{array}{r}4 \\
0.71\end{array}$ & $\begin{array}{r}5 \\
0.89 \\
\end{array}$ & $\begin{array}{r}2 \\
0.36\end{array}$ & $\begin{array}{r}5 \\
0.89\end{array}$ & $\begin{array}{r}6 \\
1.07\end{array}$ & $\begin{array}{r}8 \\
1.43\end{array}$ & $\begin{array}{r}30 \\
5.35\end{array}$ \\
\hline 7 & & $\begin{array}{r}1 \\
0.18 \\
\end{array}$ & $\begin{array}{r}0 \\
0.00 \\
\end{array}$ & $\begin{array}{r}0 \\
0.00 \\
\end{array}$ & $\begin{array}{r}0 \\
0.00 \\
\end{array}$ & $\begin{array}{r}0 \\
0.00 \\
\end{array}$ & $\begin{array}{r}0 \\
0.00\end{array}$ & $\begin{array}{r}1 \\
0.18 \\
\end{array}$ \\
\hline Total & & $\begin{array}{r}76 \\
13.57\end{array}$ & $\begin{array}{r}62 \\
11.06\end{array}$ & $\begin{array}{r}99 \\
17.64\end{array}$ & $\begin{array}{r}96 \\
17.10\end{array}$ & $\begin{array}{r}116 \\
20.71\end{array}$ & $\begin{array}{r}112 \\
19.97\end{array}$ & 559 \\
\hline
\end{tabular}

First number in each box represents the count and the second number represents the percentage. The element symbol refers to the updated Chiu and Sand (2005) code presented in Table 14.2.

Source: Table prepared by Kathleen LeBlanc.

Table 14A.7. Frequency counts and percentages for motif type in each sample group.

\begin{tabular}{|c|c|c|c|c|c|c|c|c|}
\hline Count Total \% & Sample group & \multirow{2}{*}{$\begin{array}{l}\text { Early } \\
\text { Tonga }\end{array}$} & \multirow[t]{2}{*}{ Late Tonga } & \multirow[t]{2}{*}{ West Fiji } & \multirow[t]{2}{*}{ East Fiji } & \multirow{2}{*}{$\begin{array}{c}\text { New } \\
\text { Caledonia }\end{array}$} & \multirow[t]{2}{*}{ Vanuatu } & \multirow[t]{2}{*}{ Totals } \\
\hline Motif & & & & & & & & \\
\hline A & & $\begin{array}{r}11 \\
3.93\end{array}$ & $\begin{array}{r}7 \\
2.50\end{array}$ & $\begin{array}{r}3 \\
1.07\end{array}$ & $\begin{array}{r}7 \\
2.50\end{array}$ & $\begin{array}{r}5 \\
1.79\end{array}$ & $\begin{array}{r}4 \\
1.43\end{array}$ & $\begin{array}{r}37 \\
13.22\end{array}$ \\
\hline A129 (Anson) & & $\begin{array}{r}0 \\
0.00\end{array}$ & $\begin{array}{r}0 \\
0.00\end{array}$ & $\begin{array}{r}0 \\
0.00\end{array}$ & $\begin{array}{r}0 \\
0.00\end{array}$ & $\begin{array}{r}0 \\
0.00\end{array}$ & $\begin{array}{r}2 \\
0.71\end{array}$ & $\begin{array}{r}2 \\
0.71\end{array}$ \\
\hline A131 (Anson) & & $\begin{array}{r}0 \\
0.00\end{array}$ & $\begin{array}{r}0 \\
0.00\end{array}$ & $\begin{array}{r}1 \\
0.36\end{array}$ & $\begin{array}{r}0 \\
0.00\end{array}$ & $\begin{array}{r}0 \\
0.00\end{array}$ & $\begin{array}{r}2 \\
0.71\end{array}$ & $\begin{array}{r}3 \\
1.07\end{array}$ \\
\hline A134 (Anson) & & $\begin{array}{r}1 \\
0.36\end{array}$ & $\begin{array}{r}0 \\
0.00\end{array}$ & $\begin{array}{r}0 \\
0.00\end{array}$ & $\begin{array}{r}0 \\
0.00\end{array}$ & $\begin{array}{r}0 \\
0.00\end{array}$ & $\begin{array}{r}0 \\
0.00\end{array}$ & $\begin{array}{r}1 \\
0.36\end{array}$ \\
\hline A242 (Anson) & & $\begin{array}{r}0 \\
0.00\end{array}$ & $\begin{array}{r}0 \\
0.00\end{array}$ & $\begin{array}{r}0 \\
0.00\end{array}$ & $\begin{array}{r}0 \\
0.00\end{array}$ & $\begin{array}{r}0 \\
0.00\end{array}$ & $\begin{array}{r}1 \\
0.36\end{array}$ & $\begin{array}{r}1 \\
0.36\end{array}$ \\
\hline A277 (Anson) & & $\begin{array}{r}0 \\
0.00 \\
\end{array}$ & \begin{tabular}{r|}
0 \\
0.00 \\
\end{tabular} & $\begin{array}{r}0 \\
0.00\end{array}$ & $\begin{array}{r}0 \\
0.00 \\
\end{array}$ & \begin{tabular}{r|}
0 \\
0.00 \\
\end{tabular} & $\begin{array}{r}1 \\
0.36 \\
\end{array}$ & $\begin{array}{r}1 \\
0.36 \\
\end{array}$ \\
\hline A283 (Anson) & & $\begin{array}{r}0 \\
0.00 \\
\end{array}$ & $\begin{array}{r}0 \\
0.00 \\
\end{array}$ & \begin{tabular}{r|}
1 \\
0.36 \\
\end{tabular} & $\begin{array}{r}0 \\
0.00 \\
\end{array}$ & $\begin{array}{r}0 \\
0.00 \\
\end{array}$ & $\begin{array}{r}0 \\
0.00 \\
\end{array}$ & $\begin{array}{r}1 \\
0.36 \\
\end{array}$ \\
\hline A427 (Anson) & & $\begin{array}{r}0 \\
0.00 \\
\end{array}$ & $\begin{array}{r}0 \\
0.00 \\
\end{array}$ & $\begin{array}{r}0 \\
0.00 \\
\end{array}$ & $\begin{array}{r}0 \\
0.00 \\
\end{array}$ & $\begin{array}{r}0 \\
0.00 \\
\end{array}$ & $\begin{array}{r}1 \\
0.36 \\
\end{array}$ & $\begin{array}{r}1 \\
0.36 \\
\end{array}$ \\
\hline B & & $\begin{array}{r}1 \\
0.36\end{array}$ & $\begin{array}{r}5 \\
1.79 \\
\end{array}$ & $\begin{array}{r}3 \\
1.07\end{array}$ & $\begin{array}{r}7 \\
2.50 \\
\end{array}$ & $\begin{array}{r}19 \\
6.79 \\
\end{array}$ & $\begin{array}{r}4 \\
1.43 \\
\end{array}$ & $\begin{array}{r}39 \\
13.94 \\
\end{array}$ \\
\hline$C$ & & $\begin{array}{r}0 \\
0.00\end{array}$ & $\begin{array}{r}0 \\
0.00\end{array}$ & $\begin{array}{r}0 \\
0.00\end{array}$ & $\begin{array}{r}0 \\
0.00\end{array}$ & $\begin{array}{r}1 \\
0.36\end{array}$ & $\begin{array}{r}0 \\
0.00\end{array}$ & $\begin{array}{r}1 \\
0.36\end{array}$ \\
\hline D & & $\begin{array}{r}3 \\
1.07\end{array}$ & $\begin{array}{r}2 \\
0.71\end{array}$ & $\begin{array}{r}8 \\
2.86\end{array}$ & $\begin{array}{r}2 \\
0.71\end{array}$ & $\begin{array}{r}3 \\
1.07\end{array}$ & $\begin{array}{r}1 \\
0.36\end{array}$ & $\begin{array}{r}19 \\
6.78\end{array}$ \\
\hline DE1 (Mead) & & $\begin{array}{r}0 \\
0.00\end{array}$ & $\begin{array}{r}0 \\
0.00\end{array}$ & $\begin{array}{r}0 \\
0.00\end{array}$ & $\begin{array}{r}1 \\
0.36\end{array}$ & $\begin{array}{r}0 \\
0.00\end{array}$ & $\begin{array}{r}0 \\
0.00\end{array}$ & $\begin{array}{r}1 \\
0.36\end{array}$ \\
\hline DE1.1 (Mead) & & $\begin{array}{r}0 \\
0.00\end{array}$ & $\begin{array}{r}0 \\
0.00\end{array}$ & $\begin{array}{r}0 \\
0.00\end{array}$ & $\begin{array}{r}0 \\
0.00\end{array}$ & $\begin{array}{r}1 \\
0.36\end{array}$ & $\begin{array}{r}0 \\
0.00\end{array}$ & $\begin{array}{r}1 \\
0.36\end{array}$ \\
\hline DE3 (Mead) & & $\begin{array}{r}0 \\
0.00\end{array}$ & $\begin{array}{r}0 \\
0.00\end{array}$ & $\begin{array}{r}1 \\
0.36\end{array}$ & $\begin{array}{r}0 \\
0.00\end{array}$ & $\begin{array}{r}1 \\
0.36\end{array}$ & $\begin{array}{r}1 \\
0.36\end{array}$ & $\begin{array}{r}3 \\
1.08\end{array}$ \\
\hline DE5 (Mead) & & $\begin{array}{r}0 \\
0.00 \\
\end{array}$ & $\begin{array}{r}0 \\
0.00 \\
\end{array}$ & $\begin{array}{r}0 \\
0.00 \\
\end{array}$ & $\begin{array}{r}0 \\
0.00 \\
\end{array}$ & \begin{tabular}{r|}
1 \\
0.36 \\
\end{tabular} & $\begin{array}{r}0 \\
0.00 \\
\end{array}$ & $\begin{array}{r}1 \\
0.36 \\
\end{array}$ \\
\hline DE8 (Mead) & & $\begin{array}{r}0 \\
0.00\end{array}$ & $\begin{array}{r}0 \\
0.00\end{array}$ & $\begin{array}{r}0 \\
0.00\end{array}$ & $\begin{array}{r}1 \\
0.36 \\
\end{array}$ & $\begin{array}{r}0 \\
0.00 \\
\end{array}$ & $\begin{array}{r}0 \\
0.00 \\
\end{array}$ & $\begin{array}{r}1 \\
0.36\end{array}$ \\
\hline DZC (Mead) & & $\begin{array}{r}0 \\
0.00\end{array}$ & $\begin{array}{r}1 \\
0.36\end{array}$ & $\begin{array}{r}0 \\
0.00\end{array}$ & $\begin{array}{r}1 \\
0.36\end{array}$ & $\begin{array}{r}0 \\
0.00\end{array}$ & $\begin{array}{r}0 \\
0.00\end{array}$ & $\begin{array}{r}2 \\
0.71\end{array}$ \\
\hline$E$ & & $\begin{array}{r}0 \\
0.00 \\
\end{array}$ & $\begin{array}{r}1 \\
0.36 \\
\end{array}$ & $\begin{array}{r}2 \\
0.71 \\
\end{array}$ & $\begin{array}{r}0 \\
0.00 \\
\end{array}$ & $\begin{array}{r}4 \\
1.43 \\
\end{array}$ & $\begin{array}{r}2 \\
0.71 \\
\end{array}$ & 93.21 \\
\hline$F$ & & $\begin{array}{r}3 \\
1.07\end{array}$ & $\begin{array}{r}3 \\
1.07\end{array}$ & $\begin{array}{r}3 \\
1.07\end{array}$ & $\begin{array}{r}0 \\
0.00\end{array}$ & $\begin{array}{r}7 \\
2.50\end{array}$ & $\begin{array}{r}0 \\
0.00\end{array}$ & $\begin{array}{r}16 \\
5.71\end{array}$ \\
\hline
\end{tabular}




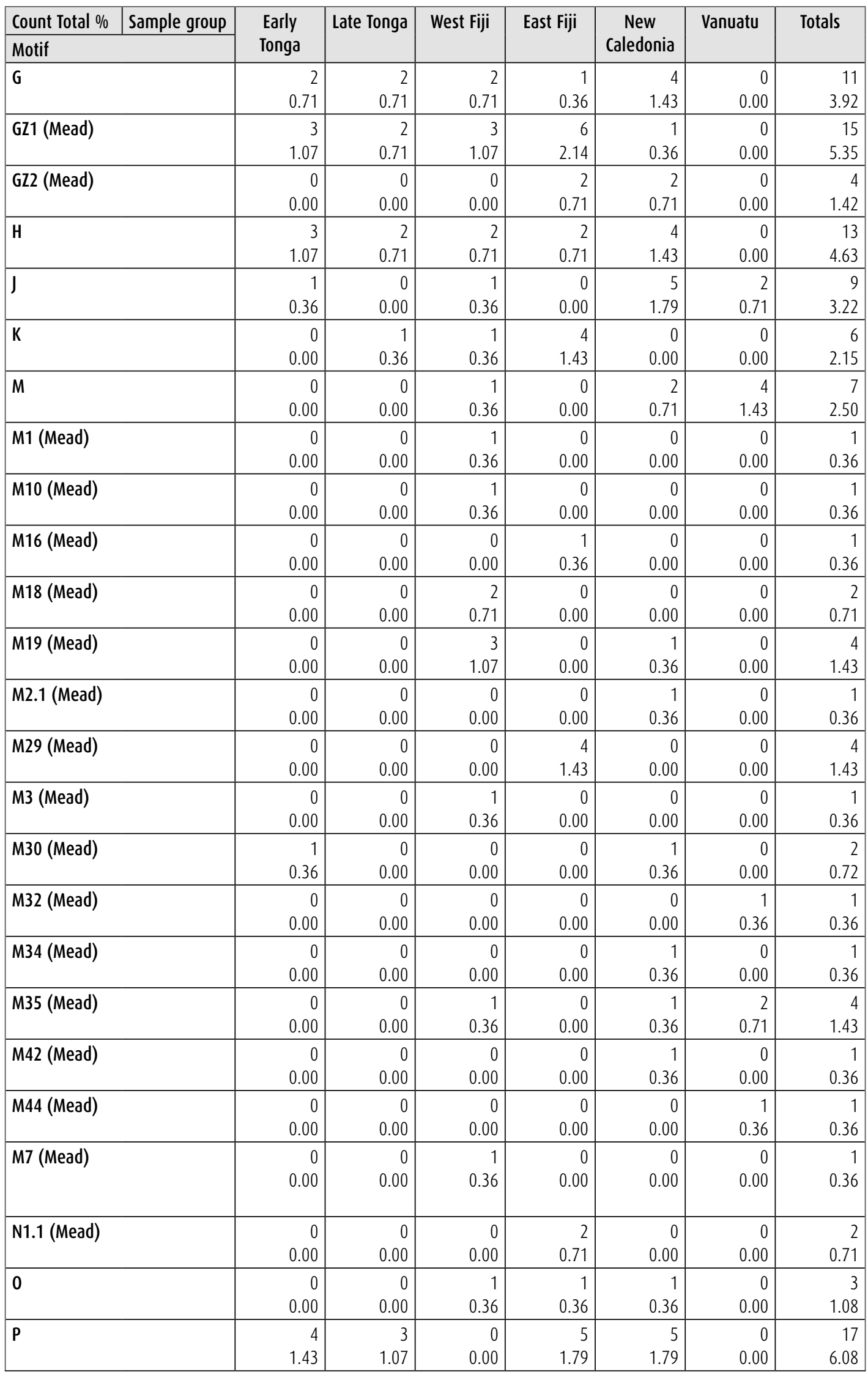




\begin{tabular}{|c|c|c|c|c|c|c|c|c|}
\hline Count Total \% & Sample group & \multirow{2}{*}{$\begin{array}{l}\text { Early } \\
\text { Tonga }\end{array}$} & \multirow[t]{2}{*}{ Late Tonga } & \multirow[t]{2}{*}{ West Fiji } & \multirow[t]{2}{*}{ East Fiji } & \multirow{2}{*}{$\begin{array}{c}\text { New } \\
\text { Caledonia }\end{array}$} & \multirow[t]{2}{*}{ Vanuatu } & \multirow[t]{2}{*}{ Totals } \\
\hline Motif & & & & & & & & \\
\hline$Q$ & & $\begin{array}{r}1 \\
0.36\end{array}$ & $\begin{array}{r}0 \\
0.00\end{array}$ & $\begin{array}{r}0 \\
0.00\end{array}$ & $\begin{array}{r}0 \\
0.00\end{array}$ & $\begin{array}{r}1 \\
0.36\end{array}$ & $\begin{array}{r}3 \\
1.07\end{array}$ & $\begin{array}{r}5 \\
1.79 \\
\end{array}$ \\
\hline$R$ & & $\begin{array}{r}0 \\
0.00\end{array}$ & $\begin{array}{r}0 \\
0.00\end{array}$ & $\begin{array}{r}2 \\
0.71\end{array}$ & $\begin{array}{r}0 \\
0.00\end{array}$ & $\begin{array}{r}0 \\
0.00\end{array}$ & $\begin{array}{r}0 \\
0.00\end{array}$ & $\begin{array}{r}2 \\
0.71\end{array}$ \\
\hline RZ1 (Mead) & & $\begin{array}{r}2 \\
0.71\end{array}$ & $\begin{array}{r}0 \\
0.00\end{array}$ & $\begin{array}{r}2 \\
0.71\end{array}$ & $\begin{array}{r}0 \\
0.00\end{array}$ & $\begin{array}{r}0 \\
0.00\end{array}$ & $\begin{array}{r}0 \\
0.00\end{array}$ & $\begin{array}{r}4 \\
1.42\end{array}$ \\
\hline RZ2 (Mead) & & $\begin{array}{r}0 \\
0.00\end{array}$ & $\begin{array}{r}0 \\
0.00\end{array}$ & $\begin{array}{r}0 \\
0.00\end{array}$ & $\begin{array}{r}0 \\
0.00\end{array}$ & $\begin{array}{r}0 \\
0.00\end{array}$ & $\begin{array}{r}2 \\
0.71\end{array}$ & $\begin{array}{r}2 \\
0.71\end{array}$ \\
\hline RZ3 (Mead) & & $\begin{array}{r}0 \\
0.00 \\
\end{array}$ & $\begin{array}{r}0 \\
0.00 \\
\end{array}$ & $\begin{array}{r}5 \\
1.79 \\
\end{array}$ & $\begin{array}{r}0 \\
0.00 \\
\end{array}$ & $\begin{array}{r}0 \\
0.00 \\
\end{array}$ & $\begin{array}{r}3 \\
1.07 \\
\end{array}$ & $\begin{array}{r}8 \\
2.86 \\
\end{array}$ \\
\hline$S$ & & $\begin{array}{r}0 \\
0.00\end{array}$ & $\begin{array}{r}0 \\
0.00 \\
\end{array}$ & $\begin{array}{r}0 \\
0.00\end{array}$ & $\begin{array}{r}0 \\
0.00 \\
\end{array}$ & $\begin{array}{r}1 \\
0.36 \\
\end{array}$ & $\begin{array}{r}0 \\
0.00\end{array}$ & $\begin{array}{r}1 \\
0.36 \\
\end{array}$ \\
\hline TB3.3 (Mead) & & $\begin{array}{r}0 \\
0.00\end{array}$ & $\begin{array}{r}1 \\
0.36\end{array}$ & $\begin{array}{r}0 \\
0.00\end{array}$ & $\begin{array}{r}0 \\
0.00\end{array}$ & $\begin{array}{r}0 \\
0.00\end{array}$ & $\begin{array}{r}0 \\
0.00\end{array}$ & $\begin{array}{r}1 \\
0.36\end{array}$ \\
\hline$Z$ & & $\begin{array}{r}3 \\
1.07\end{array}$ & $\begin{array}{r}1 \\
0.36\end{array}$ & $\begin{array}{r}0 \\
0.00\end{array}$ & $\begin{array}{r}0 \\
0.00\end{array}$ & $\begin{array}{r}0 \\
0.00\end{array}$ & $\begin{array}{r}0 \\
0.00\end{array}$ & $\begin{array}{r}4 \\
1.43 \\
\end{array}$ \\
\hline Total & & $\begin{array}{r}39 \\
13.93\end{array}$ & $\begin{array}{r}31 \\
11.07\end{array}$ & $\begin{array}{r}52 \\
18.58\end{array}$ & $\begin{array}{r}47 \\
16.79\end{array}$ & $\begin{array}{r}74 \\
26.48\end{array}$ & $\begin{array}{r}37 \\
13.21\end{array}$ & 280 \\
\hline
\end{tabular}

First number in each box represents the count and the second number represents the percentage. Where not otherwise stated, the motif symbol refers to those used in the Poulsen (1987) system.

Source: Table prepared by Kathleen LeBlanc.

Table 14A.8. Frequency counts and percentages for process type in each sample group.

\begin{tabular}{|c|c|c|c|c|c|c|c|c|}
\hline Count Total \% & Sample group & \multirow{2}{*}{$\begin{array}{l}\text { Early } \\
\text { Tonga }\end{array}$} & \multirow[t]{2}{*}{ Late Tonga } & \multirow[t]{2}{*}{ West Fiji } & \multirow[t]{2}{*}{ East Fiji } & \multirow{2}{*}{$\begin{array}{c}\text { New } \\
\text { Caledonia }\end{array}$} & \multirow[t]{2}{*}{ Vanuatu } & \multirow[t]{2}{*}{ Totals } \\
\hline Process & & & & & & & & \\
\hline \multirow{2}{*}{\multicolumn{2}{|c|}{ CLS }} & 5 & 2 & 3 & 7 & 1 & 5 & 23 \\
\hline & & 1.56 & 0.62 & 0.93 & 2.18 & 0.31 & 1.56 & 7.16 \\
\hline \multirow{2}{*}{\multicolumn{2}{|c|}{ DECR }} & 0 & 0 & 1 & 0 & 2 & 9 & 12 \\
\hline & & 0.00 & 0.00 & 0.31 & 0.00 & 0.62 & 2.80 & 3.73 \\
\hline \multirow{2}{*}{\multicolumn{2}{|c|}{ HDM }} & 0 & 1 & 1 & 0 & 7 & 0 & 9 \\
\hline & & 0.00 & 0.31 & 0.31 & 0.00 & 2.18 & 0.00 & 2.80 \\
\hline \multirow{2}{*}{\multicolumn{2}{|c|}{ INT }} & 18 & 21 & 24 & 19 & 23 & 21 & 126 \\
\hline & & 5.61 & 6.54 & 7.48 & 5.92 & 7.17 & 6.54 & 39.26 \\
\hline \multirow{2}{*}{\multicolumn{2}{|c|}{ MR }} & 4 & 2 & 0 & 6 & 0 & 3 & 15 \\
\hline & & 1.25 & 0.62 & 0.00 & 1.87 & 0.00 & 0.93 & 4.67 \\
\hline \multirow{2}{*}{\multicolumn{2}{|c|}{ RM }} & 0 & 0 & 0 & 0 & 0 & 1 & 1 \\
\hline & & 0.00 & 0.00 & 0.00 & 0.00 & 0.00 & 0.31 & 0.31 \\
\hline \multirow{2}{*}{\multicolumn{2}{|c|}{ RP }} & 25 & 22 & 20 & 17 & 25 & 20 & 129 \\
\hline & & 7.79 & 6.85 & 6.23 & 5.30 & 7.79 & 6.23 & 40.19 \\
\hline \multirow{2}{*}{\multicolumn{2}{|c|}{ SUP }} & 0 & 0 & 0 & 0 & 6 & 0 & 6 \\
\hline & & 0.00 & 0.00 & 0.00 & 0.00 & 1.87 & 0.00 & 1.87 \\
\hline \multirow{2}{*}{\multicolumn{2}{|c|}{ Total }} & 52 & 48 & 49 & 49 & 64 & 59 & 321 \\
\hline & & 16.20 & 14.94 & 15.26 & 15.27 & 19.94 & 18.37 & \\
\hline
\end{tabular}

First number in each box represents the count and the second number represents the percentage. The process symbol refers to those used in the Sharp (1988) system.

Source: Table prepared by Kathleen LeBlanc. 
This text is taken from Debating Lapita: Distribution, Chronology, Society and Subsistence, edited by Stuart Bedford and Matthew Spriggs, published 2019 by ANU Press,

The Australian National University, Canberra, Australia.

doi.org/10.22459/TA52.2019.14 